\title{
Large Shifts in Commercial Landings of Estuarine and Bay Bivalve Mollusks in Northeastern United States after 1980 with Assessment of the Causes
}

\author{
CLYDE L. MACKENZIE, Jr., and MITCHELL TARNOWSKI
}

\section{Introduction}

In U.S estuaries and bays from Maine to North Carolina (Fig. 1), commercial landings and associated abundances of the four major, commercially important bivalve mollusks have experienced large synchronous declines between 1980 and 2005. The bivalves are eastern oysters, Crassostrea virginica; northern quahogs, Mercenaria mercenaria; softshell clams, Mya arenaria; and bay scallops, Argopecten irradians spp. Their combined landings

Clyde L. MacKenzie, Jr., is with the James J. Howard Marine Sciences Laboratory, Northeast Fisheries Science Center, National Marine Fisheries Service, NOAA, 74 Magruder Road, Highlands, NJ 07732. Mitchell Tarnowski is with the Maryland Department of Natural Resources, Tawes Office Building, B-2, 580 Taylor Avenue, Annapolis, MD 21401. Views or opinions, expressed or implied, are those of the authors and do not necessarily reflect the position of the National Marine Fisheries Service, NOAA.

doi: https://doi.org/10.7755/MFR.80.1.1 declined by $85 \%$ (Table 1 ). The numbers of fishermen who harvested the bivalves declined similarly (Table 2). These downturns have deprived fishermen of their historical livelihoods, and many waterfronts that had once been dedicated to commercial fishing are now dominated by private and tourist housing, restaurants, and sporting vessels. Once common seasonal foods for coastal people, these bivalves have become far less available in consumer markets (authors' observations).

The bivalve declines are in contrast to the previous three decades (195080 ), when the combined landings of the same bivalves were much higher and the trend in each of their annual landings was nearly level, decade by decade. However, the landings of northern quahogs in Connecticut have risen sharply. The landings of American lobsters, Homarus americanus, have also increased sharply in Maine, but have fallen precipitously (from $40 \%$ to $98 \%$ ) from southern Massa- chusetts to New Jersey (see Appendix). Additionally, groups of marine and land animals have also experienced large abundance changes since the early 1980 's. For example, the landings of the 14 most important commercial marine groundfish caught on ocean bottoms off the U.S. northeastern coast fell by about $78 \%$ between 1980 and 2013 , or almost as much as the molluscan landings (NOAA Annual Commercial Fishery Landings Statistics ${ }^{1}$ ).

Our assessment of the declines in bivalve landings was undertaken to pursue one of the primary missions of NOAA's National Marine Fisheries Service: to understand how climate changes modify ecosystems and thus abundances and landings of commercial marine species. A major change to the bivalve habitats occurred when the North Atlantic Oscillation (NAO)

${ }^{1}$ NMFS Annual Landings Statistics available online at https://www.st.nmfs.noaa.gov/commercial-fisheries/commercial-landings/annuallandings/index.
ABSTRACT-Between 1980 and 2010, documented commercial landings of the four most commercially-important bivalve mollusks have declined sharply in U.S. estuaries and bays from Maine to North Carolina. The numbers of shellfishermen have declined accordingly. Landings of the following species have declined: eastern oysters, Crassostrea virginica, by 93\%; northern quahogs, Mercenaria mercenaria, by $62 \%$; softshell clams, Mya arenaria, by 66\%; northern bay scallops, Argopecten irradians irradians, by 93\%; and southern bay scallops, A. i. concentricus, by $91 \%$. Their combined landings fell by an estimated $85 \%$. In the previous three decades, 1950-80, annual landings of the same species did not decline.

The declines in landings of the bivalve mollusks were a consequence of declines in their abundances which was due to falling juvenile recruitments. The declines took place after the molluscan environments changed adversely for the bivalves as the North Atlantic Oscillation index switched its phase from negative to positive in about 1982 and usually remained there until 2003. Winters then became substantially warmer while the other seasons were also warmer, but less so. The temperature increases in winter and spring probably forced weight losses in the adult mollusks, and, consequently, they spawned fewer eggs. The increased temperature also allowed heavy feeding by pelagic copepods on phytoplankton, which left too little food available for the adult shellfish and their larvae to produce good seed recruitments. Also, predation on the juvenile recruits may have increased, which precipitated the declines.

From Long Island Sound, N.Y., through Chesapeake Bay, Md., warmer waters allowed diseases to kill many adult oysters. In some waters, higher temperatures increased the negative effects of eutrophication, and in other waters the loss of eelgrass, Zostera marina, probably contributed to degradation of habitats. This paper also discusses the role that crustaceans, i.e., pelagic copepods, shrimps, and crabs, play in the productivity of bivalve mollusk stocks. Predation by penaeid shrimp on tiny bivalve recruits is suggested as an important factor that controls bivalve abundances. The common perception that bivalve landings declined due to overfishing is reconsidered, because separate environmental factors have had a much larger effect upon their productivity. 


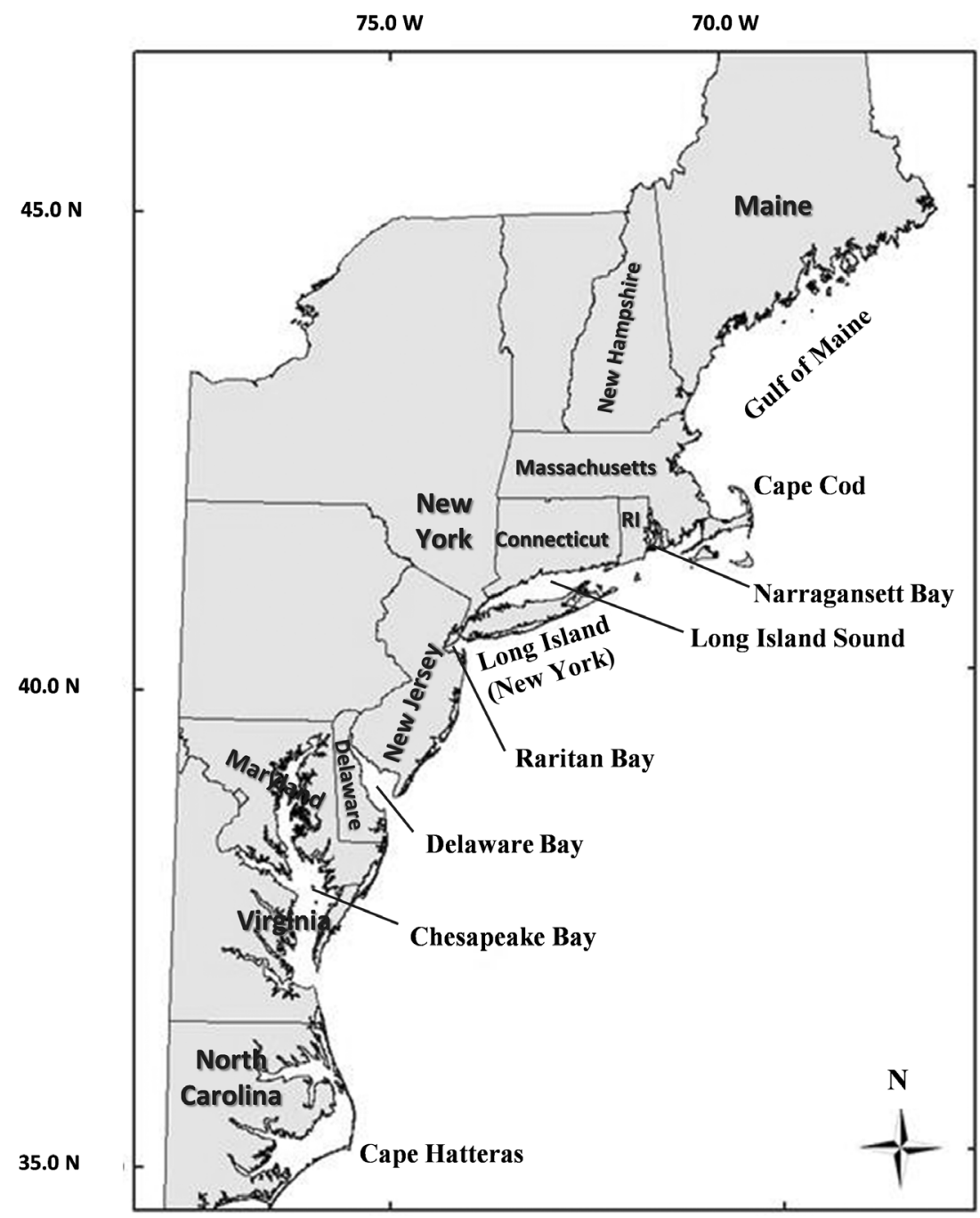

Figure 1.-The United States coastline, Maine to North Carolina, showing states and some major water bodies. index switched from negative (during about 1950 to 1980 when winter temperatures were relatively cool) to positive resulting in warmer winter temperatures from about 1982 until about 2003.

We suggest that this climate shift affected the bivalves and their associated biota enough to cause the declines. We have used research results from extensive habitat studies in Narragansett Bay, R.I., and in Europe, especially the Wadden Sea, where salinities and temperatures are similar to the northeastern U.S. coast. Collectively, these studies show that body weights of the bivalves, their nutrition, timing of spawning, and perhaps mortalities from predation were affected sufficiently to force the declines.

Other factors relating to the overall declines were eutrophication, decline in attachment sites for bivalve larvae, and weak consumer demand. Our assessment applies to the bivalves in all locations along this coast. This review is by no means comprehensive but it is sufficient to provide an overview of the salient factors that contributed to the declines.

Our findings are mainly correlative in kind because the information we collected and considered does not cover all the locations. The importance of calanoid copepod feeding on phytoplankton is mostly from the waters of Narragansett Bay, R.I., and penaeid shrimp and green crab, Carcinus maenas, predation on juvenile bivalves is mostly from the Netherlands. Our past studies on predation on oysters (MacKenzie, 1981), quahogs (MacKenzie et al., 2002), bay scallops (MacKenzie and Lind, 2013), and surf clams (MacKenzie et al., 1985) illustrated the same rapid destruction of bivalve recruits that European scientists documented. This will be discussed in a later section on European observations. We have assumed that this information roughly reflects conditions in most of the estuaries and bays of the northeast. At least one of the authors has personally visited all the major production beds from Maine to North Carolina, while accompanied by state 
personnel and local shellfishermen. Nevertheless, our conclusions are to be considered as suggestions because they are based on correlations; they can serve to drive future research. The common perception that the bivalve landings have declined mainly due to only overfishing will be reconsidered here because separate environmental factors are identified that have had much larger effects. We have not included bivalves that were produced by aquaculture (larvae reared in hatcheries) in this study.

We have included observations relating to reproduction of bivalves reported in various international publications by scientists in Europe, mainly the Netherlands, because some aspects are more extensive than those reported in the United States. The effects of predators on European bivalves probably are similar to those on the bivalves in the northeastern United States because some species are the same or closely related, such as the softshell clam, the shrimp, Crangon spp., and the green crab. Salinities are also similar.

\section{Data Collections}

Data on annual landings of bivalve mollusks were obtained from compilations by NMFS under Annual Landings Statistics ${ }^{1}$ and various states since 1950. Recordings of shellfish landings began in 1880 , both as a state and federal responsibility (Sutherlund and Koplin, 1997). Data were collected from mandatory and voluntary reporting systems, including logbooks submitted by commercial companies, and from our interviews of town and state shellfish constables, seafood dealers, and our personal observations in the bays.

Principal data consist of species landed, pounds of meat, and landed values in each state. Landings data for bivalves presented herein are in bushels ( $1 \mathrm{bu}$ equals 35 1) of whole bivalves, but whole weights of American lobsters and finfish are listed. The meat-to-bushels ratio was calculated by using conversion factors listed under Statistical Survey Procedures in the NMFS Statistical Digests (Fishery

Table 2.-Comparison of the numbers of molluscan and lobster fishermen along the U. S. east coast, Massachusetts to Virginia, in early 1980 's and early 2000 's.

\begin{tabular}{|c|c|c|c|c|}
\hline Species & Location & Early 1980's & early 2000 's & $\%$ Change \\
\hline \multicolumn{5}{|l|}{ Oyster } \\
\hline Market & Connecticut & 36 & 6 & $-83 \%$ \\
\hline Seed & Connecticut & 45 & 3 & $-93 \%$ \\
\hline Seed & New Jersey & 70 & 45 & $-36 \%$ \\
\hline Market & Maryland & 1,246 & 81 & $-93 \%$ \\
\hline & Subtotal & 1,397 & 135 & $-90 \%$ \\
\hline \multicolumn{5}{|l|}{ Quahog } \\
\hline & Great South Bay & 1,500 & 6 & $-99 \%$ \\
\hline & Connecticut & 15 & 120 & $+700 \%$ \\
\hline & Raritan Bay, NY, NJ & 180 & 40 & $-78 \%$ \\
\hline & Barnegat Bay & 30 & 5 & $-83 \%$ \\
\hline & Chincoteague Bay, MD & 30 & 0 & $-100 \%$ \\
\hline & Subtotal & 1,755 & 171 & $-90 \%$ \\
\hline \multicolumn{5}{|l|}{ Softshell clam } \\
\hline & Boston, MA & 169 & 0 & $-100 \%$ \\
\hline & Chatham, MA & 200 & 0 & $-100 \%$ \\
\hline & Raritan Bay, NJ & 18 & 0 & $-100 \%$ \\
\hline & Chesapeake Bay, MD & 225 & 0 & $-100 \%$ \\
\hline & Subtotal & 612 & 0 & $-100 \%$ \\
\hline \multicolumn{5}{|l|}{ Bay scallop } \\
\hline & Edgartown, MA & 80 & 25 & $-69 \%$ \\
\hline & Nantucket, MA & 310 & 60 & $-81 \%$ \\
\hline & Chatham, MA & 300 & 0 & $-100 \%$ \\
\hline & Peconic Bay, NY & 300 & 20 & $-93 \%$ \\
\hline & Subtotal & 990 & 105 & $-89 \%$ \\
\hline \multicolumn{5}{|l|}{ Atlantic surfclam } \\
\hline & New Jersey State waters & 80 & 0 & $-100 \%$ \\
\hline & Subtotal & 80 & 0 & $-100 \%$ \\
\hline \multicolumn{5}{|l|}{ Lobster } \\
\hline & Middle Long Island Sound & 279 & 48 & $-83 \%$ \\
\hline & Raritan Bay \& Atlantic Ocean & 56 & 0 & $-100 \%$ \\
\hline & Subtotal & 335 & 48 & $-86 \%$ \\
\hline Total & & $\overline{5,169}$ & 459 & $-91 \%$ \\
\hline
\end{tabular}

Statistics of the United States, 1970). Conversion factors for each mollusk will be listed in the landings tables.

Factors affecting the collection of landings data are under-reporting and not reporting due to confidentiality. NMFS has taken care to ensure that the data are accurate, but voluntary reporting is subject to carelessness and bias, and all possible contributors may not be identified or reported. The data are sufficiently reliable to show the trends in annual landings (Sutherland and Koplin, 1997).

Data for numbers of fishermen were collected from state records, interviews with fishermen, state and town shellfish constables, local biologists, and our personal observations. The numbers of fishermen listed represent those harvesting on the beds rather than the numbers of fishing licenses that were issued by a town or state. Data from the fisheries in every location could not be included. Trends in fishery landings described herein correspond mostly to the changing abundances of stocks, but market demand by consumers also plays a role. When demand is weak and prices are low, fishing efforts and landings commonly are less than when demand and prices are higher.

In some waters we sampled the species of pelagic copepods and ctenophores and recorded their numbers. To do so, we towed a net behind a boat for $10 \mathrm{~min}$ at each site. The net had an opening $19.8 \mathrm{~cm}$ in diameter; the mesh openings in the net were 335 microns. The mesh size was too large to retain bivalve larvae.

\section{North Atlantic Oscillation}

In the North Atlantic Ocean and surrounding continents, the index shifts of the North Atlantic Oscillation (NAO) (Fig. 2) have a dominant influence over climate variability (Hurrell, 1995) and, consequently, over ecosystems and fisheries (Ottersen et al., 2001). The state of the index affects the timing of the species' reproduction, bivalve phytoplankton foods, predatorprey relationships, and ultimately their abundances. Each estuary and bay has 


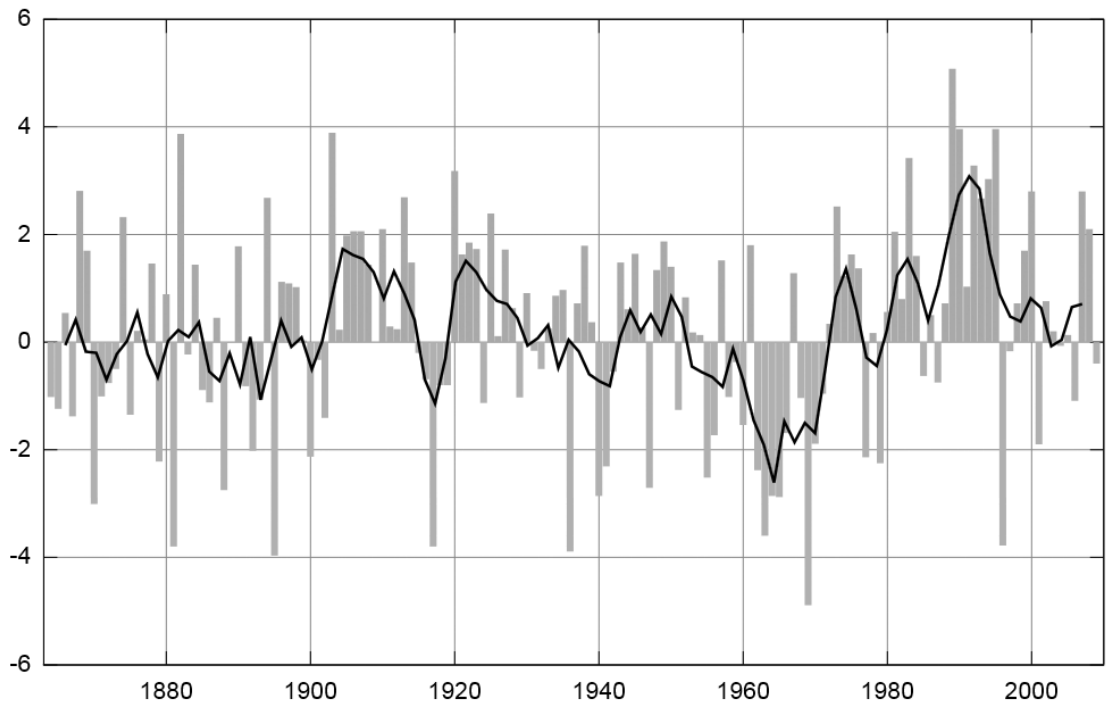

Figure 2.-Trend of the North Atlantic Oscillation index, 1865-2010; black line represents 5 year moving average. Source: NAO Index Data provided by the Climate Analysis Section, NCAR, Boulder, NSA, Hurrell (2003). Updated regularly. Accessed 08 Oct. 2017, Wikipedia.

tightly coupled ecosystems that are strongly influenced by the NAO (Kirby et al., 2009).

The NAO relates to the shifting in the atmospheric air pressure at sea level between the high pressure zone around the Azores, west of Portugal, and the low pressure zone at Iceland and Greenland. The NAO affects temperature, wind, and precipitation, especially in winter and early spring when the atmosphere is more active than in other seasons in the North Atlantic Ocean between approximately lat. $40^{\circ} \mathrm{N}$ and $60^{\circ} \mathrm{N}$ (in North America, from mid-New Jersey to northern Newfoundland; in Europe, from midPortugal to lower Norway and Sweden (Hurrell, 1995)).

When the air pressure difference is small, the NAO index phase is negative, and winters are relatively cold and dry. When in its positive phase, westerly winds are stronger than otherwise, air and seawater are warmer, most noticeably in winter, and also precipitation is heavier. Winter is the season in which the NAO has its greatest influence on bivalves and other biota (Marshall et al., 2001), and large variations in the NAO can occur among winters and also within each of the seasons (Hurrell and Deser, 2009). Thus, during the 1950 's to early 1980 's, annual bivalve recruitments by year commonly ranged from high to low, despite what appeared to be a consistently negative NAO index phase when weekly indices were averaged for a full year.

Early studies of the NAO dealt with its physical aspects (Hurrell, 1995), but investigative work since the mid1980's has been focusing on how its contrasting negative and positive indices affect marine and terrestrial populations in the United States (Hurrel et al., 2003) and Europe (Stenseth et al., 2002). Studies have shown that when marine waters warm, some fish migrate northward to cooler habitats; if fish were to remain in place, they could perish when temperatures rose above the extremes they can tolerate (Murawski, 1993; Beaugrand et al., 2002). In addition, the diseases MSX and Dermo have shifted much farther north from Chesapeake and Delaware Bays to new areas, for example into Connecticut waters where they killed many oysters (Ford, 1996; Cook et al., 1998).

In the early 1980 's, the NAO index switched to its positive phase and the rising temperature affected many groups of marine plants and animals in the United States and Europe (Ottersen et al., 2001). The groups included phytoplankton (Irigolen et al., 2000); calanoid copepods and other zooplankton (Ottersen et al., 2001; Beaugrand et al., 2002; Oviatt, 2004); jellyfish (Lynam et al., 2004; Purcell and Dekker, 2005); bivalve diseases (Soniat et al., 2009; Soniat et al., 2012a; Bushek et al., 2012); blue crabs, Callinectes sapidus (SanchezRubio et al., 2011); sea turtles (Baez et al., 2011); and the compositions of biotic assemblages along with recruitments, abundances, and growth of juvenile marine fish during their estuarine and bay residences (Dippner, 1997; Tunberg and Nelson, 1998; Ottersen et al., 2001; Parsons and Lear, 2001; Attrill and Power, 2002; Brander and Mohn, 2004; Henderson and Seaby, 2005; Aburto-Oropeza et al., 2010). The increase in winter temperature lessened cold stress and thus reduced the mortality of many animals, including juvenile Atlantic croakers, Micropogonias undulatus, in Barnegat Bay, N.J. (Hare and Able, 2006), and animals on land (Straile and Stenseth, 2007).

The NAO index might be a good predictor of interannual variability in animals and plants because of its effects on them in the early spring (Hurrell, 1995; Hurrell and Deser, 2009). Use of this index could help observers make predictions of interannual variability in the recruitment magnitudes of juveniles and hence population sizes (Straile and Stenseth, 2007). Stenseth et al. (2002) believe, though, that making firm predictions about the effects of the positive NAO index and its higher temperatures, along with its stronger winds and heavier rainfall, on abundances of biota should be tenuously considered. Nevertheless, if the role of the NAO is not considered, incorrect conclusions can be drawn regarding the relative contributions of anthropogenic vs. naturally occurring disturbances in regulating marine biological systems (Hurrell and Van Loon, 1997; Ottersen et al., 2001). 
Since the Industrial Age began in about the mid-1850's, the earth's temperature has risen by about $0.7^{\circ} \mathrm{C}$ (Bindoff et al., 2007). After about 1980, the North Atlantic Oscillation (NAO) in the United States has substantially augmented this rise, especially in winter, when it shifted to and usually remained in its positive phase. In Narragansett Bay, Mass., mostly in the warm years of the late 1980's and early 1990's, winter mean temperatures were $1^{\circ}-3^{\circ} \mathrm{C}$ above earlier means; they rose about $2^{\circ} \mathrm{C}$ from about 1970 to 1994 (Oviatt, 2004). In Chesapeake Bay waters, winter temperatures rose from $0.8^{\circ}$ to $1.1^{\circ} \mathrm{C}$ from 1950 to 2002; they correlated well with sea surface and surface air temperatures (Preston, 2004). In European estuaries, the strongest rises also occurred in winter and spring; water temperatures were about $3^{\circ} \mathrm{C}$ above the earlier winter means, $+1^{\circ} \mathrm{C}$ to $+2^{\circ} \mathrm{C}$ above spring means; $0^{\circ} \mathrm{C}$ to $1.5^{\circ} \mathrm{C}$ during summer; and $<1^{\circ} \mathrm{C}$ above means during autumn (Beukema, 1992; Kirby et al., 2008).

\section{Historical Harvesting of Bivalve Mollusks}

Many northeast U.S. coastal region communities had relied on farming, shellfishing, and finfishing for sustenance and economic benefit from prehistoric times to at least the 1940's (Ingersoll, 1881, 1887; Kochiss, 1974; MacKenzie, 1992, 1996). In the early 1900 's, the various coastal states assumed management of their shellfisheries. The states established seasons during which the bivalves could be harvested on public beds, permitted only certain gears for harvesting, and restricted the sizes and quantities to be taken by day and season. The restrictions were applied to allow the stocks to endure for an entire open season and to be sustained so the fisheries could remain viable year after year. Some grounds became available for private leasing to allow individuals to culture oysters.

The following four bivalve species comprise the majority of shellfish landings along the northeast U.S. coast. Over time, the eastern oyster was the dominant bivalve landed, and its fishery existed on a large commercial scale throughout the 1800's, 1900 's, and into the 2000's. Following in prominence has been the northern quahog whose fishery provided employment for several thousand workers along the U.S. coast from the late 1800's through the 1930's (MacKenzie et al., 2002). Commercial quantities of softshell clams have been landed in every state from Maine through Maryland. Maine usually has been the major producer, but Maryland produced about as many as Maine from the late 1950 's into the early 1990 's. ${ }^{1}$ Northern bay scallops occur in a narrow north-to-south geographic range from the east coast of Cape Cod, Mass., to southern Long Island, N.Y., a distance of $160 \mathrm{~km}(90 \mathrm{mi})$. The east-west distance is $340 \mathrm{~km}(210 \mathrm{mi})$. Scallops have been harvested in Massachusetts, Rhode Island, Connecticut, and New York. The southern bay scallop once occurred in commercial quantities in several states from New Jersey through North Carolina, and an active fishery remains in North Carolina.

After World War II, many alternate employment opportunities became available (McCay and Jenks, 1997). As the human population increased, this region has become an amalgam of large urbanized centers, suburban sprawl, and recreational facilities that have overwhelmed the relevance of bivalve harvesting and also caused some degradation to estuarine habitats. Relatively few people in the former fishing towns now actively catch bivalves for commerce or have the vocational skills related to fishing and the associated knowledge, beliefs, and behaviors that accompany them. The original waterfronts remain, but more expensive housing, tourist-related and upperscale retail shops and restaurants, and recreational boats have replaced most fishing sheds and commercial boats.

After 1980, the numbers of fishermen who harvest the coastal bivalves and lobsters from Cape Cod, Mass., to Virginia began to decline substantially (Table 2). The quantities of bivalves in the beds were falling to such an ex- tent that many fishermen found it difficult to earn a living from harvesting them, and they abandoned the industry. Some moved to jobs in other types of fisheries, but most found different types of employment; and parents have discouraged their children from entering commercial shellfishing as an occupation. By the early 2000's, the overall declines in shellfishermen averaged $89 \%$ (range, $43-100 \%$ ) for the various species.

Many who traditionally would have gone into the fisheries (because money could be made and training for the work was minimal) now seek other employment because abundances of bivalves and fish have become relatively low, working hours can be long, financial security is lacking, and incomes are often uncertain and irregular. They also lack the benefits of paid sick leave, vacations, and retirement income. Reduced bivalve fisheries now remain in many locations, based on persistent stocks and market demand for the bivalves.

\section{Historical Landings and the NAO}

\section{Oysters}

A sketch of the history of oyster landings in the northeastern U.S. from their recorded beginning in the last quarter of the 1800's to the current time will include how they were affected by the NAO, habitat degradation, "overharvesting," bacterial contamination, and market demand. Oyster production was rising to its historical peak during 1885 to 1905 (Ingersoll, 1881; Robertson, 1923; Lyles, 1969), with most of the landings from Chesapeake Bay, Delaware Bay, and Long Island Sound.

In examining the index cycles of the NAO during the 140 years from 1865 to 2005 (Hurrell, 1995; Hurrell et al., 2003; Hurrell and Deser, 2009) (Fig. 2), we note that swings in oyster landings somewhat correspond to those cycles (Table 3). When the oyster industry was developing and increasing in size from about 1865 to 1902 , the NAO index usually was 
Table 3.-General modes of the North Atlantic Oscillation (mean winter), negative modes compared with positive modes (Hurrell et al., 2003) (See Fig. 4), and oyster landings during 5 time periods, 1865 to 2010 (Lyles, 1969; NOAA Fisheries Landings Statistics).

\begin{tabular}{ccll}
\hline Time period & Years & NAO mode & $\begin{array}{c}\text { Oyster } \\
\text { landings trends }\end{array}$ \\
\hline $1865-1902$ & 37 & Negative & Increasing \\
$1903-1930$ & 27 & Positive & Poor \\
$1931-1978$ & 47 & Negative & Level \\
$1979-2002$ & 23 & Positive & Decreasing \\
$2003-2010$ & 8 & Neutral & Slightly increasing \\
\hline
\end{tabular}

in its negative phase. But when the landings were declining from 1903 to 1930 , the NAO index usually was in its positive phase. From 1931 to 1972, when the index usually was in a negative phase, annual oyster landings were relatively constant over time. In Chesapeake Bay oyster landings were somewhat level by year with no trend from about 1931 to 1959 and landings averaged about 6.6 million bu/yr (Lyles, 1969).

We point out, though, that these recorded landings are not necessarily an accurate reflection of the quantities that were available to harvest on the beds: the magnitudes of harvesting efforts by fishermen and the available consumer markets have large roles in determining annual production. Oyster landings in Long Island Sound and Delaware Bay had begun to decline during the early 1950's due to a severe storm in 1950, especially in Connecticut. From 1979 to 2002, the NAO index was in its positive phase and oyster landings declined. Then, from 2003 to 2010 , the phase was negative or in a neutral phase and oyster landings in Chesapeake Bay were somewhat increasing.

Several factors contributed to the decline in oyster landings after 1900. During the last quarter of the 1800's, heavy oyster sets were routine and the oyster industry was flourishing and increasing in size while meeting the food demands of the growing human population. Subsequently, however, the NAO index was in its positive phase and between about 1900 and 1925 , Connecticut rarely had a good set and its oyster landings declined (Robertson, 1923; Loosanoff, 1966). We suggest that the poor oyster recruitments

Table 4.-Landings of oysters (bushels $\times 1,000)^{1}$ by State, 1950-2010. ${ }^{2}$

\begin{tabular}{lrrrrrrrrrr}
\hline Year & MA & RI & \multicolumn{1}{c}{ CT } & NY & NJ & DE & MD & VA & NC & Total \\
\hline 1950 & 30.4 & 131.7 & 464.6 & $1,171.6$ & $1,207.0$ & 356.8 & $2,824.7$ & $3,109.5$ & 424.20 & $9,720.5$ \\
1955 & 22.3 & 5.7 & 53.0 & 180.5 & 867.4 & 548.4 & $3,386.6$ & $4,391.1$ & 132.9 & $9,568.0$ \\
1960 & 14.7 & 3.5 & 46.9 & 108.0 & 27.8 & 29.4 & $2,307.8$ & $3,068.1$ & 221.1 & $5,827.4$ \\
1965 & 7.8 & 1.6 & 35.1 & 26.6 & 87.2 & 5.7 & $1,690.2$ & $2,513.7$ & 157.0 & $5,524.9$ \\
1970 & 7.8 & 1.0 & 16.3 & 69.2 & 112.9 & 36.0 & $3,259.8$ & $1,608.7$ & 69.5 & $5,182.2$ \\
1975 & 8.1 & 0 & 70.0 & 280.9 & 162.0 & 32.5 & $3,216.1$ & $1,247.4$ & 77.2 & $5,094.3$ \\
1980 & 39.4 & 0 & 90.3 & 171.2 & 126.0 & 83.7 & $2,930.3$ & $1,569.3$ & 131.5 & $5,146.7$ \\
1985 & 11.7 & 0 & 112.3 & 39.8 & 48.9 & 6.6 & $1,685.7$ & 904.7 & 99.2 & $2,908.8$ \\
1990 & 4.2 & 0 & 380.1 & 106.7 & 83.4 & 0 & 565.2 & 326.6 & 59.8 & $1,525.7$ \\
1995 & --3 & 1.1 & 431.2 & 47.0 & 26.0 & 3.1 & 234.9 & 79.6 & 40.1 & 863.1 \\
2000 & -- & 13.6 & 81.0 & 9.9 & 33.7 & 13.0 & 464.4 & 32.6 & 37.0 & 687.2 \\
2005 & 15.0 & 8.0 & -- & -- & 26.9 & 14.0 & 144.0 & 3.0 & 68.7 & -- \\
2010 & 31.0 & 9.0 & -- & 9.0 & 92.0 & 12.0 & 84.0 & 79.0 & 189.2 & --
\end{tabular}

${ }^{1}$ A bushel contains about $7.7 \mathrm{lb}(3.5 \mathrm{~kg})$ of oyster meats in Connecticut and New York, and $5.1 \mathrm{lb}(2.3 \mathrm{~kg})$ of meats in Chesapeake Bay (Maryland and Virginia).

${ }^{2}$ NMFS annual commercial landings data found in U.S. Fisheries Statistics and Fisheries of the United States. 3Unknown data.

may have also occurred in the Chesapeake and Delaware Bays.

The loss of shell as a habitat component due to harvesting was another negative factor. Moore (1911) stated that in Delaware Bay (Delaware), so many shells and oysters were removed by commercial dredging boats that sections of former seed beds were left with nearly bare sand and little substrate for oyster larval settlement. Ford (1997) later described how the seed beds in the New Jersey section of Delaware Bay were partially stripped of shells by commercial dredge boats. This was followed by lower seed production from the beds.

A third factor was the falling consumer demand for oysters during the early decades of the 1900's. Beef, pork, and later finfish became much more available for consumers who gradually switched to them for food. The switch was accelerated as oyster sanitation scares among consumers arose in the early 1900's. Flush toilets were coming into widespread use, and some untreated human wastes were pouring directly into waters, contaminating oysters (Turner, 1910; Churchill, 1911; Bundesen, 1925). The contaminates included bacteria (cholera, Vibrio cholera; typhoid, Salmonella typhosa). Newspaper reports about human illnesses resulting from eating oysters caused some people to avoid eating them, especially raw (MacKenzie, 1996). Various states were forced to leave large quantities of marketsized oysters on their beds for future seasons. The last year of large oyster production in Virginia was 1907 (Lee, 1914). In 1907, fearing the oyster industry might collapse, the private oyster growers formed the Oyster Growers and Dealers Association to publicize the benefits of eating oysters (Anonymous, 1908). Still, the oyster landings continued to fall (Anonymous, 1911).

In sum, the steep fall in oyster landings after 1900 , was not simply a consequence of fishermen overharvesting oysters on the beds, as many scientists, including we authors, have routinely stated. There appeared to be consistently poor seed production during this period that was related to unfavorable climate conditions associated with the positive NAO index. Bottom shell habitat depletion from harvesting activity and silt accumulations on beds were also a factor in low recruitment. In addition, consumer demand for oysters fell sharply due to health concerns and a change in preference to meats and finfish.

\section{0-1980: No Trends in Bivalve Landings}

From 1950 to 1980, there was no trend in total annual landings of each of the bivalve species (all states combined), although there was considerable interannual variability in annual bay scallop landings. The only exception was the oyster landings between 1950 and 1965: they fell from 9.6-9.7 million bu to about 5.0-5.5 million bu, coincident with the initial epizootic mortalities in Delaware and Chesa- 


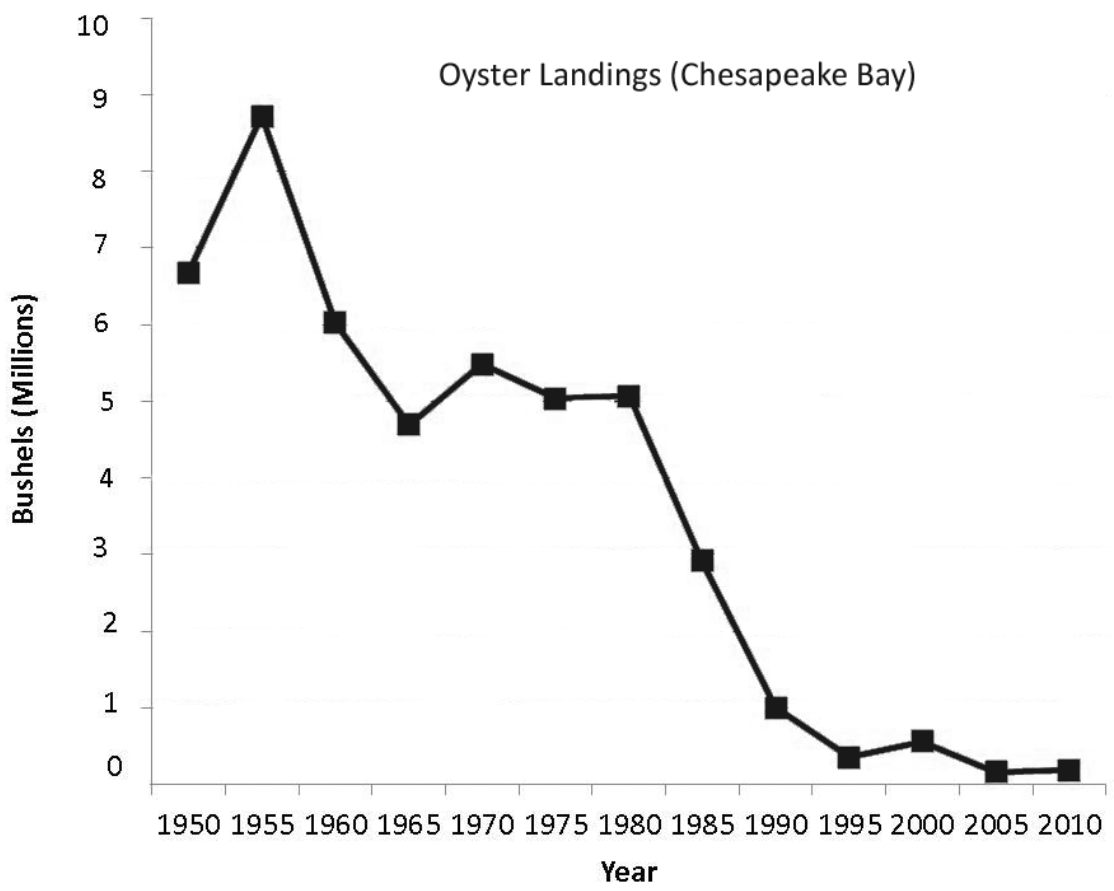

Figure 3.- Landings of oysters in Chesapeake Bay, 1950-2010. Source: U.S. Fisheries Statistics and Fisheries of the United States.

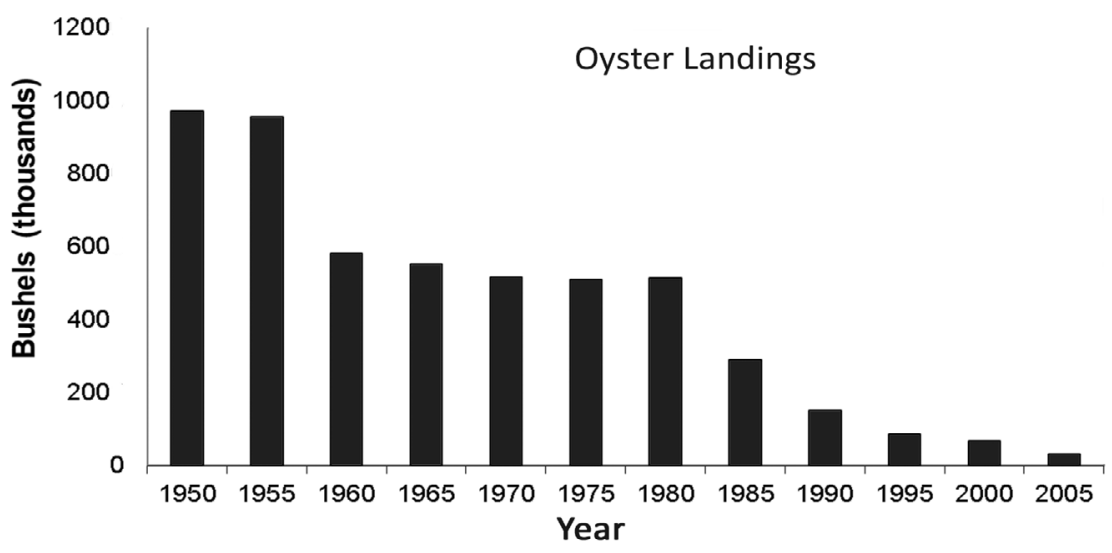

Figure 4.-Landings of oysters from Connecticut, New Jersey, Delaware, and Maryland-Virginia, 1980 to 2005. Source: U.S. Fisheries Statistics and Fisheries of the United States.

peake Bays. They remained at about this latter quantity from then until 1980 (Table 4).

Oyster landings were documented in every state from Massachusetts to North Carolina, with the largest landings from Maryland and Virginia (Chesapeake Bay) (Fig. 3), where their joint landings comprised nearly
Delaware, Massachusetts, and Rhode Island also produced substantial quantities of oysters. From 1950 to 1980, the oyster landings in Massachusetts ranged from 7,840 to $39,400 \mathrm{bu}$; landings from Rhode Island were smaller (Table 4).

The average annual landings of quahogs from the states with the highest landings were $1,250,000 \mathrm{bu} / \mathrm{yr}$ between 1950 and 1980 (Fig. 5). New York, with an average of 496,000 bu produced $43 \%$ of the total. Landings in New Jersey averaged about 210,000 bu/yr; Rhode Island, 216,000 bu/yr; Virginia, 114,000 bu/yr; and Massachusetts 113,000 bu/yr (Table 5).

Softshell clam landings from Maine to Maryland averaged $680,000 \mathrm{bu} /$ yr from 1950 to 1980 . Maine produced about 295,400 bu/yr, or about $43 \%$ of the total from all states (Fig. 6; Table 6). In 1960, 1965, and 1970, Maryland's annual average of 538,000 bu was 2.5 times higher than Maine's landings of $206,600 \mathrm{bu}$, but Maryland's landing fell considerably afterward in part due to the effects of Tropical Storm Agnes in 1972. The remaining states with substantial landings were Massachusetts with an annual average of 92,000 bu, New Jersey with 13,360 bu, Rhode Island with 9,300 bu, and New York with 7,040 (Table 6).

The average annual landings of northern bay scallops in Massachusetts, New York, Rhode Island, and Connecticut were between 290,000 and 300,000 bu (Fig. 7) (Table7), from the 1950 's to almost the mid-1980's. Massachusetts produced about $54 \%$ of this total, averaging 160,000 annually with a range between 74,220 to $225,480 \mathrm{bu}$. In 1950, New York's bay scallop landings were 4,500 bu, but in 1962 they had increased to $165,000 \mathrm{bu}$. This was the state's best year in scallop landings, and they have declined every year since then. Rhode Island bay scallop landings were relatively small; some scallops were landed in some years of the 1950's, 1960's, and 1970's, but in various years there were no landings; in 1978 there was an unusually large stock and 75,000 bu were landed. Un- 
til the mid-1960's, a bay scallop fishery was active in Connecticut. From 1953 to 1965 Connecticut's annual landings of bay scallops went from a high of $70,000 \mathrm{bu}$ down to $2,000 \mathrm{bu}$, after which the scallops became scarce and the fishery ceased to exist.

\section{0-2010: Downward Trends in Bivalve Landings}

After about 1980, the trend in landings of each bivalve mollusk was downward in most areas of the northeastern states. Annual total oyster landings fell sharply, to about 2.9 million bu in 1985, 1.5 million bu in $1990,0.7$ million bu in 2000, 0.28 million bu in 2005, and about 0.5 million bu in 2010. From 1980 to 2005, overall oyster landings declined by about 94\% (Fig. 3, 4; Table 4).

Annual northern quahog landings fell at a slower rate than did the oyster landings. By 2005, New York's landings were $135,000 \mathrm{bu}$, a decline of about $75 \%$ since about 1980 . By then, New Jersey landings were about $55 \%$ of the total from 1950 to 1975 , but they rose after 1990 and remained at about that level. By 2005, landings declines in some other states compared with those from 1950 to 1975 were: Rhode Island, 26\%; Virginia, 13\%; and Massachusetts, 43\%. From 1975 to 2005 , the overall decline in total quahog landings from all these states was about 62\% (Fig. 5, 8; Table 5).

After 1980, total landings of softshell clams from all states declined steadily (Fig. 6), and by 2000-05 they had fallen by $66 \%$ of the $1950-80$ annual totals. Maine's landings had fallen by about $20 \%$, while Maryland's landings were down by $97 \%$, and they were almost nonexistent. In New Jersey, softshell clam landings also became nonexistent. Yet the landings in Massachusetts and Rhode Island did not decline (Table 6). Softshell clam landings in Maine totaled 152,300 bu in 2000 and $138,000 \mathrm{bu}$ in 2010. The Maine landings declined mainly because state officials imposed closures of clam beds due to outbreaks of PSP (red tide), caused by the toxic dinoflagellate Alexandrium tamarense and

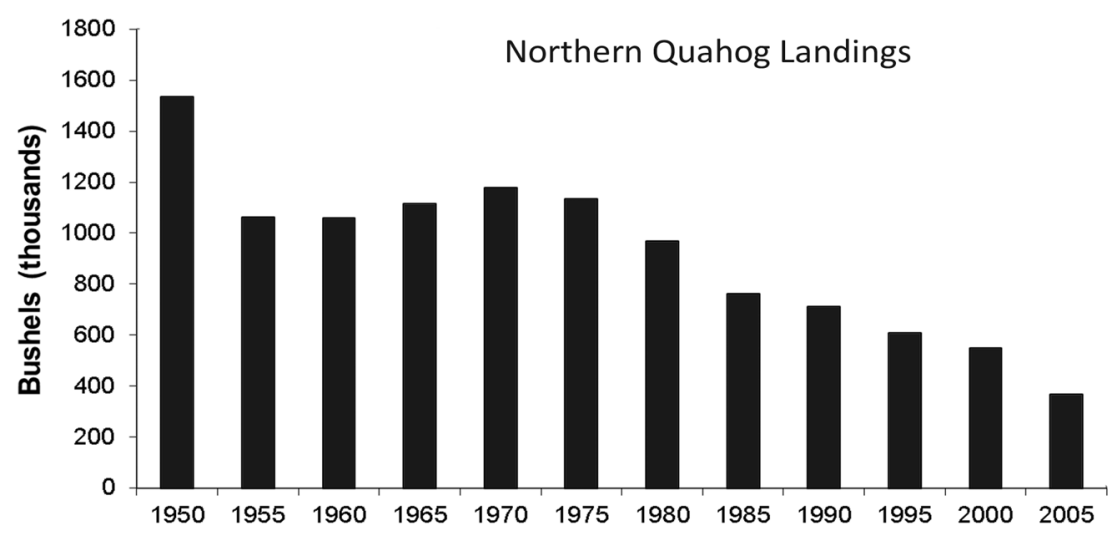

Figure 5.- Landings of quahogs in the major production states, except for Connecticut, 1950-2005. Source: U.S. Fisheries Statistics and Fisheries of the United States.

Table 5.-Landings (bushels $\times 1,000)^{1}$ of quahogs by the states with largest landings. ${ }^{2}$

\begin{tabular}{lrrrrrr}
\hline Year & MA & RI & NY & NJ & VA & Total \\
\hline 1950 & 167.8 & 185.0 & 643.0 & 423.0 & 115.0 & $1,534.5$ \\
1955 & 88.3 & 418.3 & 221.4 & 260.0 & 74.0 & $1,062.0$ \\
1960 & 117.0 & 267.0 & 324.0 & 212.6 & 138.4 & $1,059.0$ \\
1965 & 88.3 & 169.0 & 495.6 & 156.1 & 207.3 & $2,982.0$ \\
1970 & 104.8 & 90.0 & 658.8 & 214.6 & 110.8 & $1,179.0$ \\
1975 & 92.5 & 93.3 & 722.0 & 135.0 & 90.7 & $1,133.8$ \\
1980 & 133.2 & 289.8 & 412.3 & 70.4 & 62.8 & 968.4 \\
1985 & 114.3 & 345.4 & 156.4 & 86.3 & 59.8 & 762.1 \\
1990 & 91.7 & 209.6 & 205.3 & 103.1 & 129.9 & 739.5 \\
1995 & 83.3 & 108.6 & 219.0 & 118.8 & 78.7 & 608.4 \\
2000 & 62.5 & 117.0 & 196.0 & 135.0 & 37.0 & 547.5 \\
2005 & 37.2 & 53.5 & 134.7 & 154.3 & 16.0 & 395.7 \\
2010 & 75.0 & 50.0 & 117.0 & 127.6 & 12.7 & 382.3
\end{tabular}

${ }_{1}^{1} \mathrm{~A}$ bushel contains $11 \mathrm{lb}(5 \mathrm{~kg})$ of quahog meats in Massachusetts; $12 \mathrm{lb}(5.4 \mathrm{~kg})$ in Rhode Island and New York; $10 \mathrm{lb}$ $(4.5 \mathrm{~kg})$ of meat in New Jersey; and $8 \mathrm{lb}(3.6 \mathrm{~kg})$ in Virginia.

${ }^{2}$ NMFS annual commercial landings data found in U.S. Fisheries Statistics and Fisheries of the United States.

${ }^{3} \mathrm{New}$ Jersey landings rose after 1980 because a large bed of quahogs was discovered then in Sandy Hook Bay.

Fishermen harvested large quantities from it (MacKenzie et al., 2006).

high numbers of bacteria in waters where the clams were present. PSP and bacteria can cause serious illnesses to humans who consume the clams. The bed closures were frequent in summer when consumer demand and clam harvesting would be at their peaks.

In 1980, the total annual landings of bay scallops in the region from Massachusetts to Long Island, N.Y., were $297,300 \mathrm{bu}$, but they fell to $44,200 \mathrm{bu}$ by 1990 , and 600 bu in 2000 . In 2010 , the landings rose slightly to $21,400 \mathrm{bu}$; most landings were from Nantucket and Martha's Vineyard, Mass. (Table 7; Fig. 7, 9).

\section{Landings of Oysters and Quahogs Rise in Connecticut}

In contrast with the other northeastern states, oyster landings in Con- necticut rose substantially. From 1955 through 1970, annual landings were from about 16,000 to $58,000 \mathrm{bu}$, but by 1995 landings were 430,000 bu. The reasons for the increase are attributed to the commercial industry controlling two main oyster predators, starfish, Asterias forbesi, and the oyster drills, Urosalpinx cinerea and Eupleura caudata, and spreading much larger quantities of shells to be used as cultch for setting oyster larvae (MacKenzie, 1981). During the mid-1990's, the disease MSX, Haplosporidium nelsoni, infected the oysters, and they died in large numbers. The landings dropped to about 80,000 bu by 2007 . Connecticut's landings, thereafter, though substantial in volume, have not been documented.

Quahog landings averaged about $12,000 \mathrm{bu} / \mathrm{yr}$ from the 1920 's to the 
1970's. In those years just a few boats, usually employed for oystering, sought quahogs during the spring when their main activities were slow. Beginning in the early 1990's, the quahogs became much more abundant. Fishermen found large quantities of seed and littleneck quahogs on hundreds of acres of bottoms, in waters 3-12 m deep that extended from Norwalk to New Haven. The quahogs had not been present in such quantities before. Connecticut's annual landings of quahogs began to rise sharply as more boats, including those that had been used for lobstering in Long Island Sound, joined the harvesting fleet after the lobsters became scarce during the 2000's (Pearce and Balcom, 2005). During the 1980's, quahog landings increased to 46,000 $\mathrm{bu} / \mathrm{yr}$; during the 1990's they averaged $125,000 \mathrm{bu} / \mathrm{yr}$.

Beginning in the early 2000's, the quahogs became even more abundant; they averaged 334,000 bu/yr; and there were 467,000 bu in 2005 (U.S. Fishery Statistics and Fisheries of the United States) (Fig. 8, 10). We suggest that the quahogs increased in abundance because juvenile rock crabs, Cancer irroratus, a primary predator of juvenile quahogs, declined sharply in numbers in 1999. Adult rock crabs had occupied deep bottoms along with the lobsters during summers. They came into relatively shallow waters, 3-7 m deep, during winter, mated, and in the spring released their larvae. The larvae settled in the same shallow waters and fed on invertebrates, including the juvenile quahogs. Most rock crabs died when the lobsters also died in Long Island Sound during the warm months in 1999, owing to stressful environmental conditions (low oxygen concentrations and release of sulfides and ammonium from the sediments) (Pearce and Balcom, 2005). The heavy predation by the juvenile crabs on the quahogs probably then ended. More research is needed to confirm this hypothesis.

\section{Declines in Daily and Seasonal Harvests}

A tally of the quantities of bivalves taken daily by individual fishermen

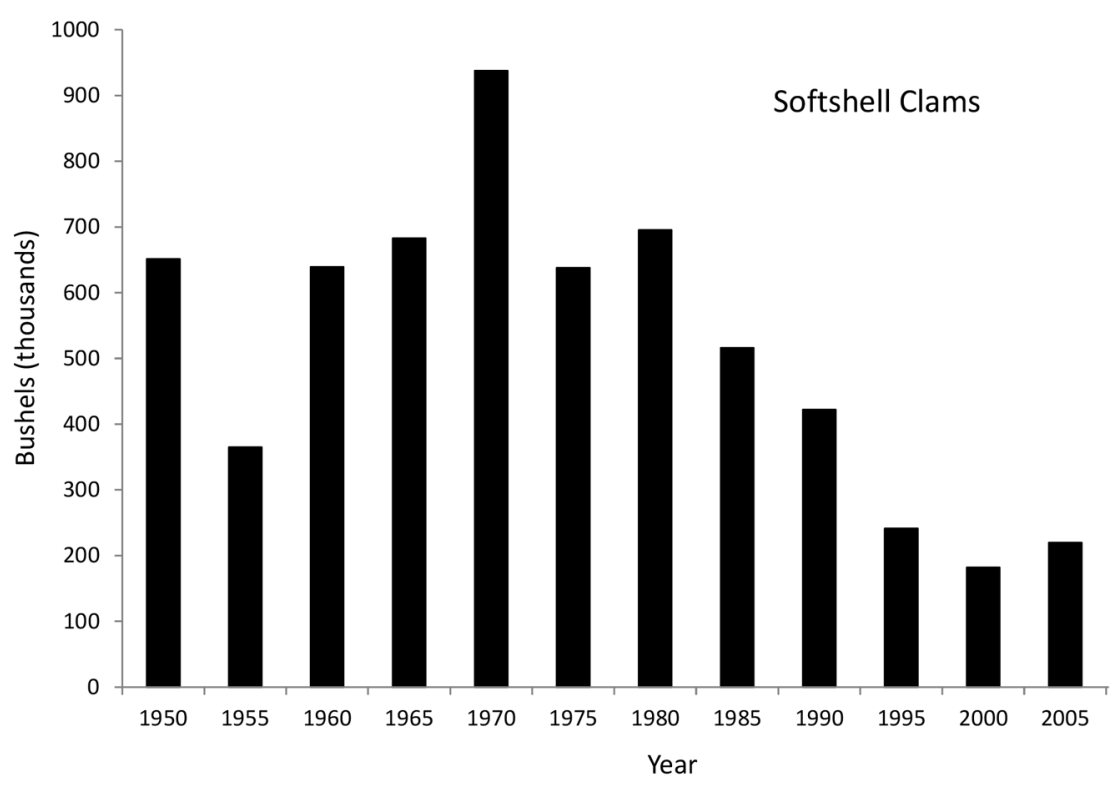

Figure 6.-Landings of softshell clams in the major production states, 1950-2005. Source: U.S. Fisheries Statistics and Fisheries of the United States.

Table 6.-Landings (bushels $\times 1,000)^{1}$ of softshell clams by state, $1950-2010 .^{2}$

\begin{tabular}{lcrrrrrr}
\hline Year & ME & MA & RI & NY & NJ & MD & Total \\
\hline 1950 & 458.5 & 116.8 & 38.5 & 2.5 & 34.6 & 0 & 650.9 \\
1955 & 174.8 & 78.5 & 0.9 & 2.7 & 8.6 & 99.5 & 365.0 \\
1960 & 138.2 & 56.3 & 0.4 & 11.8 & 3.5 & 428.4 & 639.6 \\
1965 & 130.9 & 81.2 & 13.5 & 15.9 & 2.6 & 588.8 & 832.9 \\
1970 & 350.6 & 91.4 & 6.7 & 5.7 & 5.4 & 478.6 & 938.4 \\
1975 & 436.5 & 86.4 & 1.4 & 4.8 & 13.0 & 95.9 & 638.0 \\
1980 & 378.4 & 132.5 & 3.7 & 6.0 & 25.9 & 148.1 & 694.6 \\
1985 & 316.9 & 61.8 & 0.7 & 11.1 & 24.1 & 101.1 & 515.7 \\
1990 & 167.6 & 74.4 & 1.3 & 14.2 & 0 & 164.0 & 421.4 \\
1995 & 124.4 & 76.9 & 2.6 & 12.4 & 0 & 24.9 & 241.2 \\
2000 & 152.3 & 0.3 & 1.6 & 13.9 & 0 & 13.0 & 181.1 \\
2005 & 123.8 & 58.9 & 8.4 & 20.8 & 0 & 8.5 & 220.4 \\
2010 & 138.0 & 85.0 & 3.2 & 10.0 & 0 & 2.4 & 238.6
\end{tabular}

${ }^{1} \mathrm{~A}$ bushel contains $15 \mathrm{lb}(6.8 \mathrm{~kg})$ of meat in Maine and New York, $13 \mathrm{lb}(5.9 \mathrm{~kg})$ in Massachusetts and Rhode Island, and $12 \mathrm{lb}(5.4 \mathrm{~kg})$ in New Jersey and Maryland.

${ }^{2}$ NMFS annual commercial landings data found in U.S. Fisheries Statistics and Fisheries of the United States.

over extended times can suggest whether the landings declines were actually a drop in the abundances of the bivalves. Data are available for only oysters in Maryland and bay scallops in Nantucket, but they are somewhat suspect because the data may have been collected in a year without reference to the size of the stock that year. From 1975 to 1982 , the oyster catch/fisherman in Maryland averaged $14 \mathrm{bu}$ of oysters/day, falling thereafter to $7 \mathrm{bu} /$ day (Tarnowski ${ }^{2}$ and

${ }^{2}$ Tarnowski, M. 2014. Maryland oyster population report-2013 Fall Survey. MDNR Publ. 17.8192014.723, 46 p. undocumented data). In 1978, the seasonal harvest of bay scallops landed/ fishermen license in Nantucket was 268 bu. In the 1980 Nantucket season, the seasonal catch/fishermen license was 182 bu of scallops, and in the 1990's and early 2000's it was 86 bu. These data suggest that the abundances had fallen, but the best test for determining the relative scallop abundances among years is the total landings because nearly "all", marketable bay scallops are harvested each year. Moreover, local fishermen and shellfish constables have stated that the bivalve stocks have declined. 


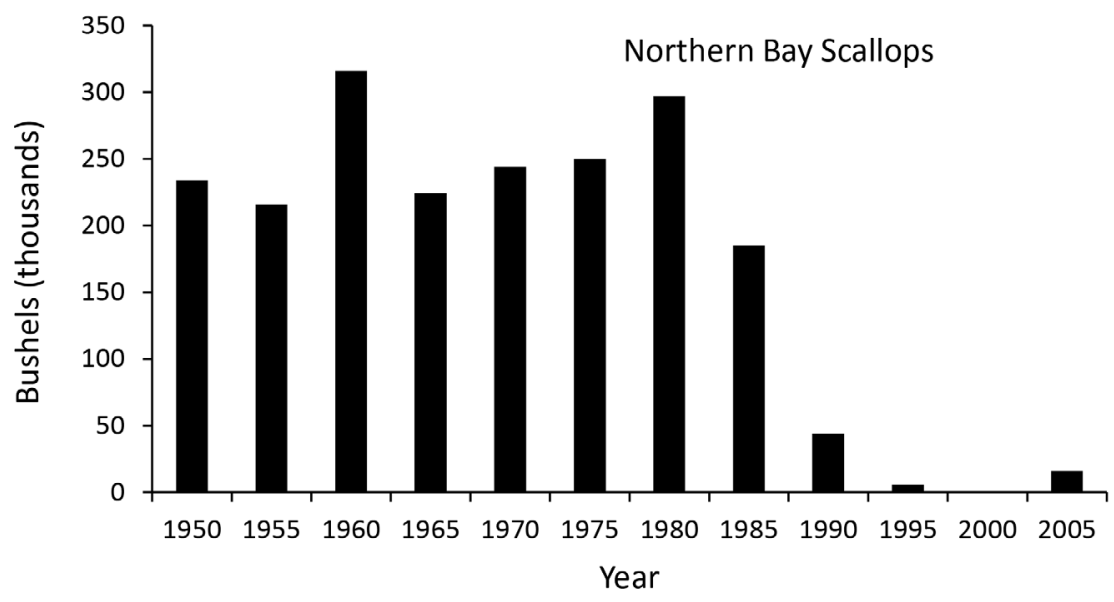

Figure 7.- - Landings of bay scallops in the major production areas, 1950-2005. Source: U.S. Fisheries Statistics and Fisheries of the United States.

\begin{tabular}{lccccc}
\multicolumn{6}{l}{ Table 7. Landings (bushels) $\mathbf{x} \mathbf{1 0 0 0})^{\mathbf{1}}$ of northern bay scallops by State, $\mathbf{1 9 5 0}$ to $\mathbf{2 0 1 0 .}^{\mathbf{2}}$} \\
\hline Year & MA & RI & CT & NY & Total \\
\hline 1950 & 164.3 & 29.8 & 35.2 & 4.5 & 233.8 \\
1955 & 145.5 & 22.1 & 10.7 & 37.7 & 216.0 \\
1960 & 154.3 & 0 & 22.9 & 139 & 316.2 \\
1965 & 74.2 & 0.4 & 2.0 & 147.7 & 224.3 \\
1970 & 183.5 & 0 & 0 & 60.8 & 244.3 \\
1975 & 175.7 & 0 & 0 & 74.0 & 249.7 \\
1980 & 225.5 & 0 & 0 & 71.8 & 297.3 \\
1985 & 156.0 & 0 & 0 & 29.0 & 185.0 \\
1990 & 42.4 & 0 & 0 & 1.8 & 44.2 \\
1995 & 4 & 1.4 & 0 & 4.3 & 9.7 \\
2000 & 0 & 0 & 0 & 0.6 & 0.6 \\
2005 & 15.0 & 0 & 0 & 1.0 & 16.0 \\
2010 & 21.2 & 0 & 0 & 0.2 & 21.4 \\
\hline
\end{tabular}

${ }^{1} \mathrm{~A}$ bushel contains 6 pounds $(2.2 \mathrm{~kg})$ of bay scallop meats

${ }^{2}$ NMFS annual commercial landings data found in U.S. Fisheries Statistics and Fisheries of the United States.

Factors Associated with

Declines in Bivalve Landings

Bivalve abundances in the U.S. northeastern states are controlled largely by the conditions of their environments whose collective substantive elements for these species apparently remained generally stable during 1950-80. However, their conditions became altered in ways that resulted in lower abundances of the bivalves between 1980 and 2005. The altered natural factors were those affected by the North Atlantic Oscillation and higher temperatures.

We recognize that some of the temperature rise may be associated with human activities, but most of this rise was a consequence of the switch of the NAO index to its positive phase. Af- fected were the spawning successes of bivalves, copepod feeding on phytoplankton, most likely predation on juvenile bivalves, diseases in oysters, and declines in eelgrass. Direct human factors causing degradation to bivalve environments have been eutrophication, siltation of oyster beds, deterioration of oyster shell availability (partially from commercial harvesting actions), and hydrodynamic alterations (e.g., changes in salinity and current regimes due to inlet stabilizations) (Table 8). The strength of consumer demand has also affected commercial bivalve landings.

\section{Natural Factors Affecting Bivalve Recruitments}

University of Rhode Island (URI) researchers may have been among the first in the United States to relate changes in marine environments to the $\mathrm{NAO}$, noting that after the NAO shifted to its positive index in the early 1980's waters became warmer. Populations of demersal finfishes decreased, but pelagic finfish and benthic crustaceans increased in Narragansett Bay, R.I., and nearby waters (Jeffries and Terceiro, 1985; Keller and Klein-MacPhee, 2000; Oviatt, 2004; Collie et al., 2008). They also found that abundances of zooplankton (mostly copepods) and phytoplankton changed substantially.

Zooplankton grazing on phytoplankton was continuous during the warmer winters and was responsible for a winter-spring decline in phytoplankton. The zooplankton actively fed, even reproduced, and grazed down the phytoplankton during the warmer winters. In spring and early summer, copepods continued feeding on the phytoplankton, keeping its abundance down (Keller et al., 2001; Oviatt et al., 2002; Oviatt, 2004). During any cold winters, the zooplankton were relatively inactive, and in the following spring and early summer the phytoplankton had relatively large blooms (Keller et al., 1999, 2001; Sullivan et al., 2001). Our survey results in Massachusetts show the same zooplankton pattern relating to changing abundances of copepods and ctenophores (Table 9).

The observations on zooplankton feeding on phytoplankton in winter were supported by Smayda (1990), Li and Smayda (1998), and Collie et al. (2008) who found that the phytoplankton declined substantially in Narragansett Bay even though the concentrations of nitrogen remained about the same. The potential effect on bivalves of the NAO index switch in phase to positive by modifying the composition of the phytoplankton species was explained by Smayda et al. (2004) as follows: "Climate change appears capable of modifying the baseline community of phytoplankton; as it changes in species' compositions and abundances, it affects the grazer species including the bivalves that have to adjust to it and thereby their abundances are altered." 


\section{Bivalves Failed When NAO Positive Phase Peaked in the Late 1990's}

When the positive phase of the NAO index was at its peak and temperatures were very warm during 198995, recruitments and landings failures were documented in oysters, softshell clams, and bay scallops (Table 10). In the 12-yr period from 1994 to 2004, oyster spatfall in Virginia rivers failed while little or no sets of oyster larvae occurred. Delaware Bay (New Jersey) had little or no sets of oyster larvae from 1998 to 2003. Maryland experienced the lowest oyster harvest in 150 years during the 1993-94 season. After rebounding from Tropical Storm Agnes in the 1970's, Maryland's softshell clam landings fell during the 1980 's. In the early 1990's, they fell more sharply and in 1995 and thereafter little of the commercial industry remained. Bay scallop landings declined during the 1980's, but collapsed from 1994 through 2003 to the extent that they barely existed. Their landings increased afterward.

\section{Other Bivalve Decline Factors}

\section{Predation on Larvae and Juveniles}

The highest bivalve mortalities undoubtedly occur in their pelagic larval stages (Rumrill, 1990). Depending upon location, their most likely predators include larval crustaceans (mostly larval shrimp and crabs), the benthic anemone, Diadumene leucolena (MacKenzie, 1977; Steinberg and Kennedy, 1979), ctenophores (Burrell and Van Engle, 1976; Purcell et al., 1991; McNamara et al., 2010), and certain fishes, including cyprinodonts (MacKenzie and Lind, 2013).

Laboratory observations have shown that some of these predators can consume bivalve larvae rapidly: $D$. leucolena can clear most late-stage oyster larvae in a small fish aquarium within 24 hours. D. leucolina may have a huge importance because its individuals often occupy much of the space on benthic bottoms in Delaware and Chesapeake Bays (MacKenzie, 1977).

Table 8. -Small-scale changes in various habitats have had negative effects on bivalve habitats and stocks. On Martha's Vineyard, Mass., a severe storm broke a 1-mile-wide opening through a 3-mile bar forming the south side of Katama Bay. Small fisheries ongoing for bay scallops, northern quahogs, and softshell clams ended because their habitats were destroyed.

On Martha's Vineyard, Mass., Sengecontacket Pond became eutrophic and the eelgrass all died, ending the pond's ability to harbor bay scallops.

In Chatham on Cape Cod, Mass., a storm broke an opening through the Monomoy Island sand bar and destroyed softshell clams and their habitats inside the bar, ending an active fishery.

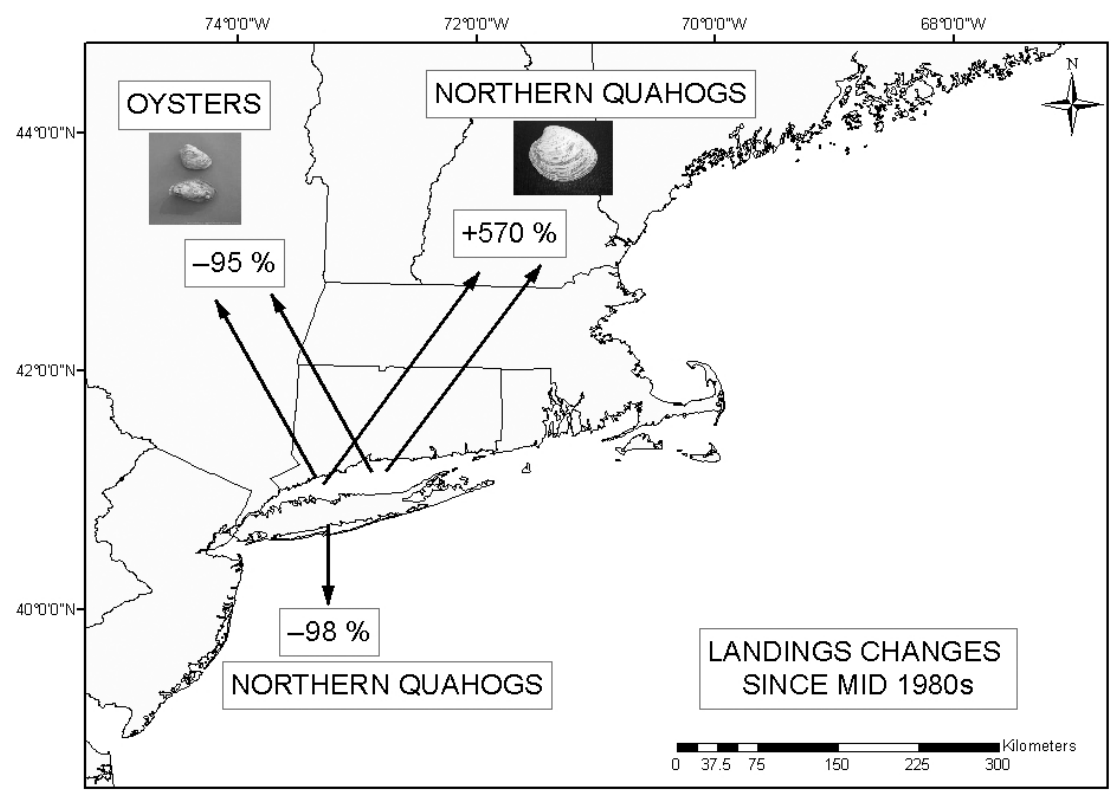

Figure 8.-Coastlines from Maine to New Jersey showing changes in landings of oysters and northern quahogs in Connecticut and New York.

Bivalves usually suffer heavy predation after they have metamorphosed and set on substrates. The predators include crustaceans, gastropods, and small fish. The various predators of oysters, quahogs, and softshell clams include mud crabs (family Xanthidae) that may be the most widespread and important predator; rock crabs; flat worms, Stylochus spp.; starfish, Asterias forbesi; at least three species of shrimps; oyster drills, Urosalpinx cinerea and Eupleura caudata; moon snails, Euspira heros and Neverita duplicata; striped killifish, Fundulus majalis; and mummichogs, $F$. heteroclitus.

Since the early 1950's, many studies have shown that individual predators can consume post-set juvenile bivalves rapidly, and juvenile mortality rates are usually high (Hanks, 1952; Carriker, 1957; Webster and Medford, 1961; Haskin and Tweed, 1976; Mackenzie, 1981; MacKenzie et al., 1985; Newell et al., 2000; MacKenzie and McLaughlin, 2000; Polyakov et al., 2007; MacKenzie and Lind, 2013). MacKenzie (1981) described the results of a 5-yr survey of predation and other factors that affected abundances of oysters from settlement of spat to market-sized oysters in Connecticut. White and Wilson (1996) wrote a comprehensive chapter titled, "Predators, Pests and Competitors" in the book, The Eastern Oyster Crassostrea virginica. Kraeuter (2001) described "Predators and Predation" in the Elsevier volume, Biology of the Hard Clam. Newell et al. (2000) described predation by flatworms on oysters in 
Chesapeake Bay. Kulp et al. (2011) described how mud crabs prey heavily on oyster spat in Chesapeake Bay.

In Massachusetts, bottom predators of juvenile bay scallops are shrimps, including the sand shrimp, Crangon septemspinosa; Xanthid mud crabs; green crabs; and at least five species of small fishes. The grass shrimps Paleomonetes pugio, and zostera shrimps, Hippolyte zostericola, can feed on scallops when they are attached to eelgrass blades (MacKenzie and Lind, 2013). The scallop juveniles that have settled directly on the sediment bottom in areas devoid of eelgrass likely suffer huge losses from predation by sand shrimp, mud crabs, and small fishes such as gobies, Gobiosoma bosc; juvenile cunners, Tautogolabrus adspersus; and scup, Stenotomus versicolor, that prey on juvenile scallops of about $12 \mathrm{~mm}$ in height.

Long-term surveys of bivalve predators have not been done to determine the magnitudes of any changes in their abundances among years, but it has been observed that increases have taken place in blue crabs in the waters of Chesapeake Bay, U.S. southeast, and northward into New England; green crabs in Massachusetts; and crustaceans in Narragansett Bay (Oviatt, 2004; Collie et al., 2008). When the NAO index was mostly positive and temperatures were warmer after 1980, daily and seasonal feeding rates of the predators may have been higher (Table 11).

We have observed that mortality rates owing to predation are relatively low in these four bivalve species after they attain a height of perhaps $40 \mathrm{~mm}$ (and after their first winter) to when they are sufficiently large for commercial harvests (authors' observations). For instance, dredged samples of bivalves taken from commercial beds when the bivalves are mid- to market-sized (1-3 yr) reveal that most are alive; the samples commonly have relatively few "boxes" (empty, articulated bivalve shells). But in Connecticut, Delaware Bay, and Chesapeake Bay, where the diseases MSX and Dermo have killed many oysters after they attain mid-sizes, 2-3 cm (Ford,

Table 9. -Zooplankton collected in Cape Poge Pond, Nantucket Harbor, and four locations in Buzzards Bay, Mas-

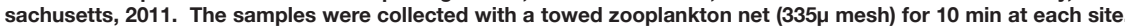

\begin{tabular}{|c|c|c|c|c|c|}
\hline \multirow[b]{2}{*}{ Date } & \multicolumn{2}{|c|}{ Cape Poge Pond } & \multicolumn{2}{|c|}{ Nantucket Harbor } & \multirow{2}{*}{$\begin{array}{c}\text { Buzzards Bay } \\
\text { Total zooplankton² }\end{array}$} \\
\hline & Zooplankton ${ }^{1}$ & Ctenophores & Zooplankton ${ }^{1}$ & Ctenophores & \\
\hline June 6-7 & 211 & 0 & 3,020 & 0 & 4,738 \\
\hline June $20-21$ & 224 & 0 & 775 & 0 & 5,019 \\
\hline July 5-6 & 13,976 & 0 & 37,520 & 0 & 2,821 \\
\hline July $18-19$ & 15,672 & 0 & 11,548 & 0 & 362 \\
\hline August 1-2 & 227 & 30 & 130 & present $^{3}$ & $\mathrm{~N} / \mathrm{A}$ \\
\hline August $15-16$ & 1 & 40 & 15 & 40 & 98 \\
\hline
\end{tabular}

TThis total includes copepods, and larvae of shrimp, crabs and barnacles, but not ctenophores.

${ }^{2}$ This total includes copepods, and larvae of shrimp, crabs and barnacles, and also ctenophores. ${ }^{3}$ Not counted.

Table 10.-Recruitment or landings failures of oysters, softshell clams, and bay scallops in specific locations during the mid-1990's and early 2000's. Correlations of poor recruitments or landings with the North Atlantic Oscillation in a high positive index from 1989 to 1995, followed by 2 negative index years, 1996 and 1997, and then three more positive index years, 1998-2000.

Oysters

Virginia Data on oyster spatfall available from Virginia Institute of Marine Science Special Reports. ${ }^{1}$ The data are average total spat/shell/yr from shell strings in the Piankatank, Great Wicomico, and James Rivers.

4 yr period: 1990 through 1993, 26.9 spat/shell.

12 yr period: 1994 through 2005, 5.6 spat/shell.

10 yr period: 2006 through 2015, 96.7 spat/shell.

Delaware Bay, NJ Data on spatfall (Powell et al., 2006).

New Jersey's oyster setting stopped for 6 yr from 1998 through 2003

Softshell clams

Maryland

Landings were falling during the 1990's. The landings were 310,000 bu in 1989 , but they were 25,000 bu in $1995 ; 2,000$ bu in $2000 ; 8,500$ bu in 2005 ; and 1,155 bu in 2014

Bay scallops

Massachusetts

Landings had been falling during the 1980's, but were 42,400 bu in $1990,94,000$ bu in 1992 , and 23,000 bu in 1993 . Then the landings fell sharply. In the subsequent 11 years from 1994 through 2003, the landings ranged from none to about 200 bu, then 2,200 bu in 2004. The landings afterward became higher and in the 10 years from 2005 through 2014. They averaged 25,270 bu/yr.

${ }^{1}$ Supplied by M. Southworth, VIMS staff.

Table 11.-Predators that increased their feeding rates when temperatures were increased from lowest to highest temperature tested, laboratory observations. The salinities were from 26.5 to 32 ppt.

\begin{tabular}{lcccl}
\hline Species & $\begin{array}{c}\text { Temperature } \\
\text { range }\left(\mathrm{C}^{\circ}\right)\end{array}$ & Prey & $\begin{array}{c}\text { Feeding rate } \\
\text { increase }\end{array}$ & \multicolumn{1}{c}{ Source } \\
\hline Flatworm, S. ellipticus & $5-21$ & oysters & $4.3 \mathrm{X}$ & (Landers and Rhodes, 1970) \\
Smooth drill, U. cinerea & $15-25$ & oysters & $3.1 \mathrm{X}$ & (Manzi, 1970) \\
Rough drill, E. caudata & $15-25$ & oysters & $4.6 \mathrm{X}$ & (Manzi, 1970) \\
Moonsnail, Euspira and Naverita & $2-21$ & softshell clam & $10.4 \mathrm{X}$ & (Hanks, 1952) \\
\hline
\end{tabular}

1997), their "boxes" can be numerous in dredged samples from beds.

Before the late 1950's, oysters growing in the area from Chesapeake Bay through New England were generally free of diseases, at least those that caused any substantial mortalities. Since then, two parasites, MSX and Dermo, have caused huge losses in oyster populations in Delaware and Chesapeake Bays. The increase in mortalities is a primary reason why commercial oyster landings fell sharply (Andrews et al., 1962; Haskin et al., 1966; Ford and Tripp, 1996).

In subsequent years, some resistance to MSX in the oysters as a re- sult of natural selection has occurred, and commercial oyster production has since increased (Haskin et al., 1966; Ford and Haskin, 1982; Ford and Tripp, 1996; Ford, 1997). Nevertheless, the percentage of Maryland oysters that died from the two diseases was about $10 \%$ in 1985 , but it then increased to $22 \%$ in $1986,44 \%$ in $1987,46 \%$ in 1999 , and was $58 \%$ in the extreme drought year of 2002 . The mortality rate afterward fell when freshwater input to Chesapeake Bay returned to normal or above flows, and by 2003, when temperatures were cooler, mortalities were $5 \%-6 \%$ (Tarnowski). 


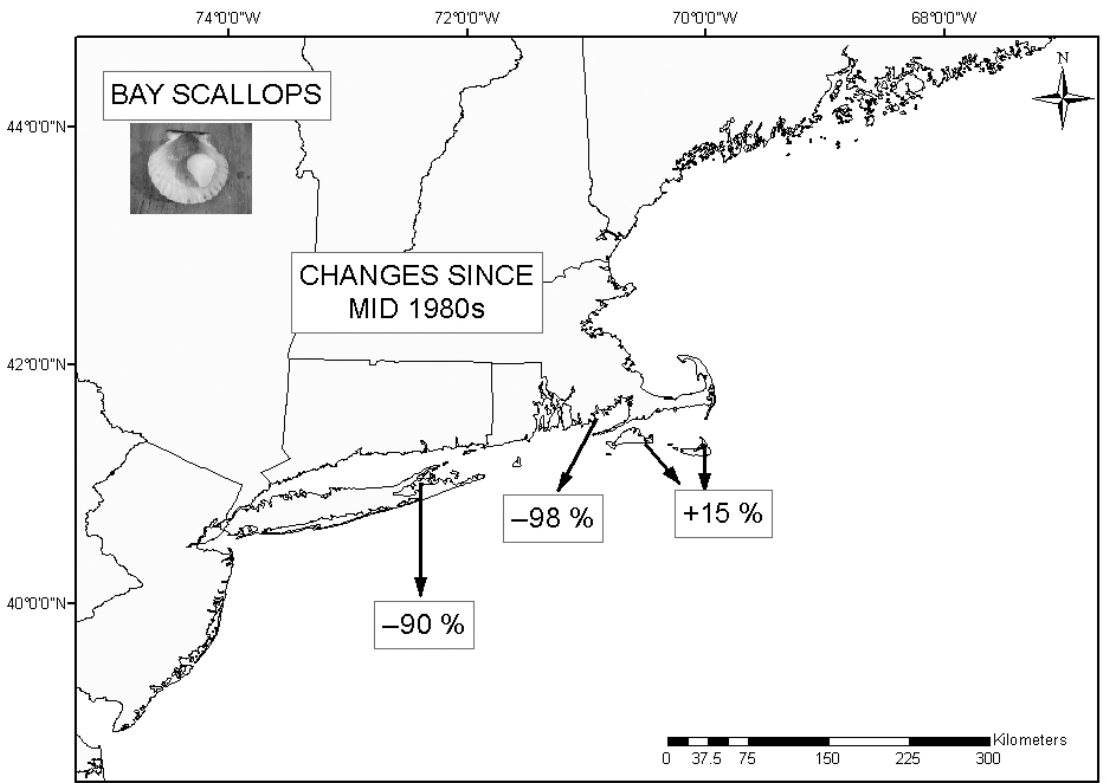

Figure 9.-Declines in bay scallop landings since mid-1980's; arrows point to major production locations.

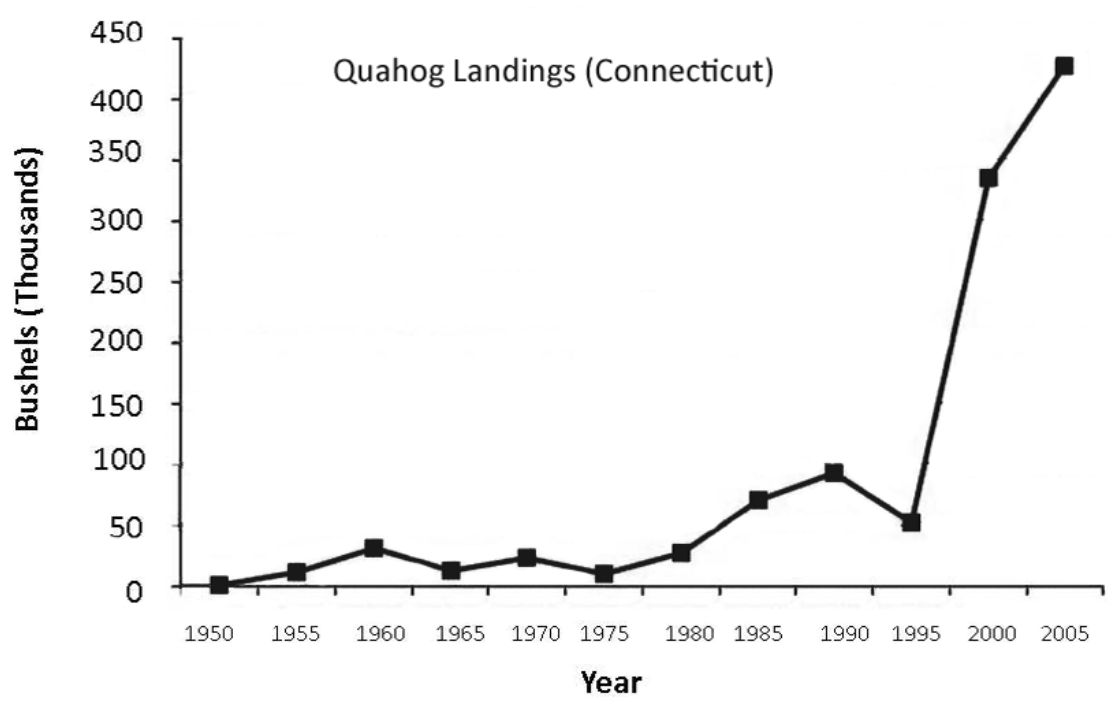

Figure 10.-Landings of quahogs in Connecticut, 1950 to 2005. Source: U.S. Fisheries Statistics and Fisheries of the United States. Note: the 2005 quahog landings were 47,000 bu.

In the mid-1990's MSX killed most of the oysters in Connecticut. These oysters previously had been free of deadly diseases and oyster landings had been increasing for the previous 20 years owing to effective culturing by private oyster growers. The effects of MSX on Connecticut oysters have been low (Anderson et al., 2003; Dove et al., 2004; Lyons et al., 2007; Smolowitz; Sunila $^{4}$ ).

Physical stress on bivalves from parasites may be higher in warming waters (Harvell et al., 2002). In Maryland, commercial populations of softshell clams are at the southern end of their range. Increasing temperatures and at least two diseases, disseminated neoplasia and infections of Perkinsus chesapeaki, may have been responsible for the steep drop in landings of this species during the 1990's from which the population has yet to recover. Populations of another commercially-important bivalve, the stout razor clam, Tagelus plebeius, were also found to be infected with disseminated neoplasia and $P$. chesapeaki when they suffered high mortalities in northern Chesapeake Bay in 2003 (Homer et al. ${ }^{5}$ ).

\section{Habitat Declines}

\section{Eelgrass}

Eelgrass "meadows," composed of many thin blades $4-10 \mathrm{~mm}$ wide and typically $20-50 \mathrm{~cm}$ long, form plant canopies over shallow estuarine and bay bottoms. The meadows often occupy extensive areas of some bays from Maine to North Carolina, and in the Canadian Maritimes from Nova Scotia to Quebec and Newfoundland (Fonseca and Uhrin, 2009). Eelgrass meadows can provide suitable environments for bay scallops and other molluscan species, crustaceans, fish, and other taxa. These animals are far more abundant in the meadows than in unvegetated sand bottoms nearby (Heck and Orth, 1980; Orth et al., 1984; Sogard and Able, 1991; Hanson, 2004; Fonseca and Uhrin, 2009; MacKenzie and Lind, 2013). On sand bot-

${ }^{3}$ Smolowitz, R. M. 2000. Roger Williams Univ., Bristol, R.I. Personal commun.

${ }^{4}$ Sunila, I. N.D. Report from Connecticut Department of Agriculture. Bureau of Aquaculture and Laboratory. Date: 2000.

${ }^{5}$ Homer, M., C. F. Dungan, and M. Tarnowski. 2001. Assessment of Chesapeake Bay commercial softshell clams, Mya arenaria and Tagelius plebeius, with emphasis on abundance and disease status. Completion Rep. to NOAA Ches. Bay Fish. Sci. Prog., NAO7NMFS4570326. 
toms without eelgrass and Gracilaria, bay scallop larvae may find only scattered stones on which to set (Marshall, 1947).

The presence of eelgrass is important for bay scallops. When water current flows strongly, eelgrass blades lean over, come closer together, and most water overflows them (Fonseca et al., 1983; Fonseca and Cahalan, 1992). Eelgrass meadows can also dampen the effects of waves during storms on shallow bottom habitats. In their absence, storms may wash scallops into piles within shallow channels, where many die, and also fatally onto beaches (Fonseca et al., 1983; Eckman et al., 1989).

We suggest that the canopies may entrap scallop eggs and sperm during spawning in the relatively still water within the meadows, thereby increasing the likelihood of fertilization. In an absence of eelgrass, these gametes likely become scattered and fewer larvae would result.

Taylor $^{6}$ suggests that eelgrass serves to maintain scallop larvae in bays. Based upon laboratory studies in which he observed that bay scallop larvae swim upward in cool waters and downward in warm waters, he concluded that during flood tides the larvae probably swim upward into the cooler waters that enter bays through inlets from sounds outside and are carried farther into the bays and away from the inlets. About $6 \mathrm{~h}$ later, when the bays' waters have warmed and the ebb tides begin, the larvae descend toward the bottom to or into the eelgrass canopies and are retained in the bays. Without eelgrass, few larvae might be retained in the bays. Most areas that have lost their eelgrass have also lost their scallops.

Another important feature of the presence of eelgrass is that their blades present an attachment surface for scallop larvae, which has many times the area of the flat-bottom surface below.

\footnotetext{
${ }^{6}$ Taylor, R. E. 1985. The ascending and desending of larvae of bay scallops, Argopecten irradians, in relation to water temperature. Unpubl. manuscr. on file, P.O. Box 1652, North Falmouth, MA 02556
}

In Massachusetts, eelgrass canopies are fully grown by early June and are present when bay scallops spawn and their late-stage larvae are present in late-June-August. The larvae attach to the blades and then as juveniles suspended above the bottom, they are safe from large losses to bottom predators. However, some losses do occur to predation by grass shrimp, Paleomonetes pugio, and the shrimp, Hippolyte zostericola, that live in the canopies. Scallop larvae also set directly on the bottom and those likely suffer large losses from predation by sand shrimp, small Xanthid crabs, and small fishes, such as gobies, Gobiosoma bosc; and juvenile cunners, Tautogolabrus adspersus. The scallops attached to eelgrass eventually drop to the bottom after growing to a height of about 10 $11 \mathrm{~mm}$. By this size, they are too large for most bottom predators to consume (Belding, 1910).

Eelgrass has declined in many places (Fonseca and Uhrin, 2009). Eelgrass and bay scallops once lived together on the shallow-water bottoms adjacent to the south shore of Cape Cod in Nantucket Sound, and in Buzzards Bay, Mass.; Narragansett Bay, R.I.; Peconic Bay, Long Island, N.Y.; Barnegat Bay, N.J.; and Chincoteague and Chesapeake Bays (Orth and Moore, 1983; Fonseca and Uhrin, 2009), but both species now are much less abundant or absent in these locations. Documented causes of the eelgrass losses include high nitrogen loads and eutrophication (Fox et al., 2008; Kennish et al., 2010), shading by dense phytoplankton blooms, dark silted water, and loose algae (Oviatt et al., 2003; Kennish et al., 2013). Another cause is high temperatures as its upper temperature tolerance is about $25^{\circ} \mathrm{C}$ (Zimmerman et al., 1989; Bintz et al., 2003; Fonseca and Uhrin, 2009).

\section{Setting Substrates}

Availability of substrate surfaces on which ready-to-set larvae of bivalves can successfully attach and grow is a large factor that controls the recruitments of juveniles (primarily oysters and bay scallops but also quahogs and perhaps softshell clams). Historically, a huge problem for oyster populations, which create their own habitat for settling larvae, has been the decline of setting substrates. As oyster populations have declined from their formerly large expanses, increasingly less shell substrate for setting larvae has been produced or remained.

When oyster populations were large, substrate areas could be maintained by regular or occasionally large widespread sets of spat. Such sets cannot occur anymore, because when a huge spawning does take place, nearly all the larvae perish due to a lack of substrates. On Connecticut's uncultivated beds, where salinities are about $27 \mathrm{ppt}$, few shells remain on large areas where earlier productive beds were once present. Some shells and oysters were buried by severe winds storms and any shells and stones that remain on the sand bottom surface are covered by bryozoans, barnacles, sponges, or silt, rendering them unable to receive oyster larvae. In Delaware Bay (Delaware) and Chesapeake Bay, where salinities may be 10-18 ppt, some shells are covered with so much silt that oyster larvae are prevented from setting (MacKenzie, 1983).

Visual surveys of active oyster beds (MacKenzie, 1981, 1983) in Delaware Bay (New Jersey) and Chesapeake Bay (Maryland) revealed that large bottom areas had only a partial cover of shells and live oysters. In Delaware Bay, about $30 \%$ of the bottom on some beds had too few shells to support oyster harvesting, and much of the shell material consisted of small oyster shell pieces, $10-30 \mathrm{~mm}$ across, that tended to lay flat on the bottom and collect too much silt to allow settlement of invertebrate larvae.

These bottoms had been dredged extensively by oystermen over the years and much original shell cover had been removed or broken into small pieces. In describing substrate loss in Delaware Bay, N.J., Powell et al. (2006) showed that when recruitment of oyster juveniles had stopped for about 6 yr (from 1998 to 2004), almost half the shell on bed surfaces was lost ow- 
ing to bioerosion, breakage, and dissolution. Soniat et al. (2012b) found that whenever fishermen harvest oysters while returning blank shells to the beds, the quantity of shell removed slightly exceeds the original quantity that had been present on the beds.

Such shell losses do not occur on every type of oyster bed as was shown by a study in the James River, Virginia, by Woods et al. (2005). Most beds in this river consist of deep deposits of densely-packed oyster shells, mixed with mud, that extended as much as 4 $\mathrm{m}$ below the bed surface. Oyster seed was removed nearly annually from some of these beds by hand tongers from the 1870 's to the 1940 's. During that time, their harvesting of seed was lowering average heights of the beds by $0.47 \mathrm{~m}$ (Woods et al., 2005). Even as the beds were lowered, the entire surface of shells remained to provide adequate substrates for oyster larvae. Spat abundances did not decline from year to year on such beds except when silt covered them (MacKenzie, 1983).

In some locations, quahogs can be abundant in sandy substrates that have shell mixed into them to provide them cover from predation (Wells, 1957; Homer et al. ${ }^{5}$ ). MacKenzie et al. (2006) found that quahogs require an environment of densely-spaced amphipod tubes, Ampelisca abdita, occurring on a mud bottom to set and survive, at least in Sandy Hook Bay, N.J. The tubes presumably serve the same function as obstacles to predators, and they also stabilize the mud surface, likely a survival benefit for tiny post-set quahogs. MacKenzie and Pikanowski (2004) showed that digging quahogs with a hand rake in sand bottoms does not affect the bottom as a habitat for the setting of invertebrate juveniles, since the grain size of the bottom surface was not altered by the raking.

Softshell clams also tend to occur in higher abundances in the mud/sand mixtures containing shell (Homer et al. ${ }^{5}$ ). The hydraulic escalator dredge used in harvesting these clams in subtidal areas in Maryland may re-sort the sediments and redistribute the shell.
The bottom afterward may have a surface of fine sand devoid of shell, and the altered surface forms a different setting substrate for the next generation of clam larvae. There is no documentation to assess whether such harvesting affects clam recruitment.

As mentioned above, eelgrass meadows are an important habitat for bay scallops, and their extent has declined in many locations. However, the bay scallops on Martha's Vineyard and Nantucket Harbor have made use of an alternative, the red alga, Gracilaria sp. (phylum Rhodophyta), which has overgrown much of the eelgrass, leaving it alive but lying close to the bottom and unavailable to the scallops. Scallop larvae set readily on Gracilaria and this alga is a poor habitat for the scallop predators, such as the shrimps, mud crabs, and fishes, and thus few are present. The scallops have been abundant in the areas that Gracilaria covers because many survive predation after setting.

In the coastal estuaries and bays from south of Cape Cod to North Carolina, the distribution of some bivalves may potentially move northward or to deeper waters when the habitat becomes warmer, similarly to the surfclams, Spisula solidissima, off the Delmarva coast (Weinberg, 2005). But if they attempted to occupy new habitats, their abundances might not be the same because they may encounter adverse habitat or environmental conditions, such as too few shells, hypoxic/ anoxic conditions, different sediment grain sizes, different biota, and their larvae could be subjected to different water currents. Softshell clam populations in Chesapeake Bay cannot move from the warmer shallows to deeper water because dissolved oxygen concentrations are often too low. Several factors have been demonstrated to affect distributions of various invertebrates: sediments (Sanders, 1956; Snelgrove et al., 1999; Compton et al., 2009), sediments and benthic fauna (Galtsoff and Loosanoff, 1939), macroalgal assemblages (Vaz-Pinto et al., 2013), and depths and currents (Loosanoff and Nomejko, 1956).

\section{Human Factors}

Several direct human factors affect bivalve environments. These include eutrophication, unintentional removal of shells (cultch) from beds during oyster harvests (as described above), hydrodynamic alterations, and siltation of oyster beds.

In the U.S northeast, some estuaries and bay waters have been receiving large quantities of land-based nutrients (mainly nitrogen but also phosphates) and other pollutants via surface runoffs and ground waters. ${ }^{7}$ The nutrients are delivered in streams and rivers draining urban centers, farms, and by atmospheric deposition (NRC, 2000; Boesch et al., 2001; Cloem, 2001; Howarth et al., 2002). Such waters become eutrophic to varying degrees. Productivity of animals and plants in waters depends on externally supplied nutrients (Mahoney et al. ${ }^{8}$ ), but nutrient over-enrichment and eutrophication have led to large increases in phytoplankton biomasses (Edwards et al., 2001).

The consequence has been large phytoplankton blooms, low oxygen concentrations on the deepest bottoms, especially in summer, and a general degradation in the biota of some coastal and bay waters and bottoms (Boesch et al. (2001). The nitrogen and other nutrients probably affect entire food webs as they flow through them (Nixon, 1995; Boesch et al., 2001; Rabalais, 2002).

During the mid-1950's to mid1980's, eutrophication in Chesapeake Bay increased by at least $40 \%$ because the bay's ecosystem absorbed loads of nitrogen and phosphates that increased by about 7 - and 18-fold, respectively. During this time, the human population in its watershed nearly doubled, and the use of inorganic fertilizer nearly tripled (Crossett, 2004). Little

\footnotetext{
${ }^{7}$ The waters include Buzzards Bay, Narragansett Bay, Great South Bay, Raritan Bay, Barnegat Bay, Chesapeake Bay, and Chincoteague Bay.

${ }^{8}$ Mahoney, J. B., P. S. Olsen, and D. Jeffress. 2006. Bloom history of picoplankter Aureococcus anophagefferens in the New Jersey Barnegat Bay-Little Egg Harbor system and Great Bay, 1995-1999. NMFS Northeast Fish. Sci. Cent. Ref. Doc. 06-08, 54 p.
} 
scientific documentation exists on the precise effects of eutrophication and hypoxia on living resources (Boynton et al., 1996; Boesch et al., 2001; Kirby et al., 2007). Major fluctuations are common in nutrients and phytoplankton at time scales ranging from every two weeks to once a month as well as seasonally and interannually (Turner et al., 2006).

A review of eutrophication effects on bivalve abundances cannot be considered directly because the temperature has risen simultaneously with it in the same locations since the early 1980's. Kroncke et al. (1998) believe that climate variability may have a larger effect on benthic ecosystems than eutrophication and some other possible factors, but Paerl (2006) suggests it has been difficult to distinguish between these two effects. Nitrogen enrichment does lead to increases in shell growth and soft tissues in quahogs, softshell clams, and bay scallops (Carmichael et al., 2004; Wall et al., 2011, 2013). Anoxia can occur when phytoplankton blooms die in eutrophic waters, killing larvae and postset bivalves.

We cannot explain how eutrophication actually affects bivalve productivity without knowing how changes in phytoplankton species and abundances affect the bivalves. Substantial changes have been documented in the phytoplankton dynamics in Chesapeake Bay and in the lagoons along the U.S. east coast due to their eutrophication and higher temperatures: 1) the phytoplankton has shifted toward communities with abundant picoplankton and nanoplankton, and 2) the species composition changed from an assemblage consisting mainly of immobile centric diatoms to one composed of flagellated species (Harding, 1994; Bricelj and Lonsdale, 1997; Kennish, 2001; Trice et al., 2004; Wasniak and Gilbert, 2004; Kemp et al., 2005; Mahoney et al. ${ }^{8}$; Bricelj $\left.{ }^{9}\right)$.

${ }^{9}$ Bricelj, V. M. 2000. Perceptives on possible factors influencing the abundances of hard clams. In C. J. Schlenk (Editor), Transcript of the workshop on hard clam population priori-
In Narragansett Bay, a decrease in diatoms coincided with an increase in dinoflagellates (Smayda, 1973) and small phytoplankton species (Oviatt et al., 1989). There also have been changes in the timing, qualities, and sizes of the phytoplankton blooms (Officer et al., 1984). The food web alterations likely modify the benthic communities in bay waters considerably (Rabalais, 2002; Marcus, 2004; Smayda et al., 2004; Paerl, 2006). Bay scallops have become scarce in Buzzards Bay, Mass. This may be in part due to a shift in the bay's phytoplankton composition, which can include dense blooms of the dinoflagellate Cochlodinium polykrikoides that they cannot use as food (Tang and Gobler, 2009).

Eutrophication and higher temperatures (also higher salinity in Great South Bay) may have allowed the picoplankter Aureococcus anophagefferens to form dense blooms, leading to the decline in northern quahogs in each of the largest east coast lagoons, namely, Great South Bay, Barnegat Bay, and Chincoteague Bay (Kennish et al., 2007). The waters of the three lagoons are mostly 1-2 $\mathrm{m}$ deep, and flushing and circulation are limited by their small inlets. These waters once had been relatively clear, but the blooms usually have made them turbid and brown. Nuzzi and Waters (1989) have categorized them as being "bloom sensitive." Factors associated with the A. anophagefferns blooms are warm temperatures, still winds, and clear skies that result in high radiance.

Quahogs cannot use A. anophagefferns as food, and recruitments of their juveniles consequently have failed (Kennish, 2001; Bricelj and McQuarrie, 2007; Newell et al., 2009). During blooms, quahogs and bay scallops have difficulty feeding, few can spawn, and growth of their larvae is severely reduced; little reproduction of either species occurs and bay scallops usually die (Black and Kassner, 1988; Bricelj and McQuarrie, 2007; Newell et al., 2009)

ties for the south shore of Long Island, N.Y. Sea Grant. N.Y. p. 81-88.
After 1975, commercial landings of quahogs from the bays declined: in Great South Bay by $100 \%$ (N.Y. State Official Commercial Fishery Landings), and Barnegat Bay by $98 \%$ $\left(\right.$ NJDEP data $\left.^{10}\right)$. In Chincoteague Bay, clam densities dropped by $92 \% .^{11}$

In some bays, excess nitrogen has also led to increases in biomasses of the seaweeds Cladophora spp., Gracilaria spp. (Orth and Moore, 1983; Boesch et al., 2001), and sea lettuce, Ulva lactuca (Tyler, 2007). Drift algae can form dense mats that smother bivalves and shade eelgrass habitats (Taylor et al., 1995: Raffaelli, 2000; Tyler, 2007; Tarnowski et al. ${ }^{12}$ ) Eelgrass remains in some areas that receive relatively low, but not high, nitrogen loads (Hauxwell et al., 2003; Fox et al., 2008).

\section{Siltation of Substrates}

Silt that accumulates on oyster beds has been a large factor that caused declines in oyster abundances. Its effects likely began during the early 1800 's, when farmland was first being plowed to raise crops. Delaware and Chesapeake Bays have large watersheds on which farming has been practiced extensively. Each spring, rainwater carries silt downstream from the fields, and some falls on oyster beds where stream flows slow in velocity as they spread into the estuaries (Ingersoll, 1881, 1887; Lee, 1914; Whitney, 1994; MacKenzie, 2007). Siltation is greatest in coves where water currents are relatively low.

\section{Recent European Observations: The NAO and Warming Temperatures}

In the early 1980's, the NAO shifted to its positive index, and thus, in

\footnotetext{
${ }^{10}$ NJDEP Division of Fish and Wildlife. Nacote Creek Research Station. Port Republic, N.J.

${ }^{11}$ The decline in Chincoteague Bay hard clam landings was also due to legislation banning mechanical harvesting (MD DNR Office, Annapolis, MD).

${ }^{12}$ Tarnowski, M., M. Homer, and R. Bussel. 1999. The re-establishment of the bay scallop in Chincoteague Bay. Final rep. NMFS, NERO, Proj. No. 95-FIG-078, Grant No. NA66FK0086, Annapolis, Md., 69 p.
} 
winter, waters were warming in European marine habitats (Beaugrand and Reid, 2003). The temperatures rose about $0.2^{\circ}-0.6^{\circ} \mathrm{C}$ per decade at least until about 2005-06 (MCCIP $\left.{ }^{13}\right)$. In European estuaries, the highest temperature rises also occurred in winter and spring; water temperatures were about $3^{\circ} \mathrm{C}$ above the earlier winter means, $+1^{\circ} \mathrm{C}$ to $+2^{\circ} \mathrm{C}$ above spring means; $0^{\circ} \mathrm{C}$ to $1.5^{\circ} \mathrm{C}$ during summer; and $<1^{\circ} \mathrm{C}$ above means during autumn (Beukema, 1992; Kirby et al., 2008).

More phytoplankton appeared following cold winters (Martens, 2001; Fransz and Gieskes, 1984; van Beusekom et al., 2009) as it did in Narragansett Bay, R.I. The European scientists have not considered the feeding of pelagic copepods as a factor being responsible for low phytoplankton quantities after warm winters.

\section{Effects on Bivalves}

Along the west coast of Europe, the distribution of Baltic tellin clams, Macoma balthica, has moved an estimated few hundred $\mathrm{km}$ northward from the previous warm edge of its range. They died in the southernmost areas where mean water temperatures are about $1{ }^{\circ} \mathrm{C}$ higher than they had been (Beukema et al., 2009; Jansen et al., 2007). The distribution of oysters, Crassostrea gigas, also shifted northward, and for the first time their larvae settled and grew on blue mussel, Mytilus edulis, beds in the German section of the Wadden Sea (Brandt et al., 2008).

In Europe, as is true in the U.S. northeast, Kroncke et al. (1998) have shown that interannual variability of animal abundances is a consequence of climate variability. Beukema et al. (1998), Beukema et al. (2009), and Beukema and Philipparte (2010) found that annual recruitments of juvenile bivalves can vary by two to three orders of magnitude. and they are governed by temperature rather than by the number of adults and the number of eggs they produce.

\footnotetext{
${ }^{13}$ MCCIP. 2010. www.mccip.org.uk/annual-reortcard/2007-2008.
}

Numbers of cockle and blue mussel spat usually peak after cold winters. The bivalves may have evolved a strategy designed to time their recruitments to the most optimal environmental conditions for them in the spring and early summer. The bivalves profit fully from the phytoplankton bloom in late June, then they set on the bottom and grow too large for their predators, identified as juvenile shrimps and also crabs, before these predators arrive on beds. Whenever the bivalves spawn earlier due to warm winters and thereby miss the phytoplankton bloom, their recruitments may be low (Beukema and Dekker, 2005).

\section{Lower Recruitment}

Europeans have studied bivalve recruitments on natural beds extensively. All the bivalves have been declining in recruitment, biomass, and annual abundances as the climate has been warming owing to the positive NAO index and worldwide warming (Beukema, 1993; Honkoop et al., 1998; Beukema et al., 1998; Strasser and Günther, 2001; Strasser et al., 2001; Strasser, 2002; Beukema and Dekker, 2005; Nels et al., 2006). During warm winters, the bivalves have a relatively high metabolic rate that results in large losses in their body weights. In the years when winter water temperatures were from $0^{\circ} \mathrm{C}$ to $3^{\circ} \mathrm{C}$, overall winter weight loss in the Baltic tellin was about $15 \%$; whereas when temperatures were from $5.5^{\circ} \mathrm{C}$ to $7^{\circ} \mathrm{C}$, the losses ranged from $33 \%$ to $40 \%$.

The consequence of weight loss, presumably mostly glycogen, that would have been used to develop gametes in the spring, was a smaller production of eggs and sperm in the following spring and summer. This species spawns 1.5 to 7 times more eggs after a cold winter vs. a warm winter (Beukema, 1992; Honkoop and Beukema, 1997; Honkoop and van der Meer, 1997, 1998; Beukema et al., 2009). Researchers believe, however, that this variation in egg production may translate into a minor part of the variation in bivalve recruit densities (Honkoop et al., 1998).

\section{Juveniles Lost to Predation}

Most studies of predation of European bivalves were conducted on tidal flats in the Wadden Sea, but the observations were similar to those made over wider areas in this sea (Beukema and Philippart, 2010; Dekker and Beukema, 2014). Huge losses of larvae occur when they are pelagic with additional mortalities after they set on the bottom to become constituents of benthic communities. During the first weeks of their benthic lives, mortality rates in European juvenile bivalves and some other marine invertebrates due to predation likely extend well above 90\% (Grosslein and Qian, 1997; Beukema and Dekker, 2014). Strong year-classes of bivalves appear to arise only when abundances of predators are low (Reise, 1993; Beukema et al., 1998; Strasser, 2002; Beukema et al., 2009).

In the Wadden Sea, brown shrimps and green crabs are the most important predators of the bivalves. After the warm winters, shrimp abundances have been from 2 to 10 times higher than after cold winters, and the numbers of green crabs are also higher (Beukema, 1991, 1992). Green crabs, as recently-settled juveniles and as older crabs, prey heavily on small juvenile bivalves but usually kill fewer than the shrimps because they arrive later and are less abundant (van der Veer and Bergman, 1987; Beukema and Dekker, 2014). Juvenile bivalves, especially the Baltic tellin, cockle, and blue mussel, are easy prey for shrimps as soon as they settle onto bottoms and huge losses of them occur (Beukema, 1992; Reise, 1993; Pihl and Rosenberg, 1984; Pihl, 1985; Honkoop and Beukema, 1997; van der Veer et al., 1998; Caceras-Martinez and Figueras, 1997; Edwards, 1997; Dijkema, 1997; Goulletquer and Heral, 1997; Hammer, 1997; Kristensen, 1997; Seaman and Ruth, 1997; Ruano, 1997; Strasser et al., 2001; Strasser, 2002; Philippart et al., 2003; Beukema and Dekker, 2005).

In the Netherlands, Keus (1986) found during one warm season that 
brown shrimps consumed 500 newlyset Baltic tellins $/ \mathrm{m}^{2}$. The bivalves can survive after they become too large, a height of at least $3 \mathrm{~mm}$, to be eaten by even the largest brown shrimps.

In the Wadden Sea, the observations of factors that appear to have the most control over bivalve recruitment are summarized by Beukema and Dekker (2014). They stated that critical interactions regarding recruitments between the bivalves and their environments occur when the bivalve larvae initially settle to the bottom and begin growing, and that:

1) The stock recruitment relationship usually is negative: recruitment of juvenile bivalves bears only a little relationship to the size of the adult spawning stocks, except when such stocks become extremely low or when most substrates for larval settlement are absent.

2) Bivalve recruitments usually are successful in summers that follow cold winters, probably because abundances of the predators are low.

3) Long-term abundances of shrimp were becoming higher, and this could help to explain the declining numbers of bivalve recruitments. (The shrimp numbers did not rise everywhere in European waters (Tulp et al., 2012).)

4) There were similar relationships between recruitments and winter temperatures in the Baltic tellins, cockles, softshell clams, and blue mussels. Between-year variation in magnitude of recruitment was synchronized among these bivalves. Their numbers peaked together after cold winters and were low after warm winters.

Dekker and Beukema (2014) report that just-settled predaceous shrimps can be present simultaneously with just-settled bivalve larvae after both cold and mild winters; both arrive later after cold winters. They further state that recruitment success can be predicted at about 1 or 1.5 mo after the annual occurrence of a mass set- tlement of larvae, because afterward predation taking place has only minor effect on ultimate bivalve abundances.

\section{Recent U.S. Consumer Demand for Oysters: Continuing Weak and Then a Shift to Stronger}

Dedah et al., (2011) has examined why during the 1990's and early 2000's landed prices of oysters were falling somewhat and why production of oysters produced by aquaculture (hatcheries) was stagnating in the United States. The fears about eating raw oysters was lingering in potential consumers, and these were enhanced by media reports that described labels displayed on sales counters in California and other states warning people about the potential danger of eating raw oysters.

Further weakening of consumer demand for bivalves came when media reports that the waters, oysters, and other seafoods taken from U.S. state waters on the Gulf of Mexico contained dangerous amounts of bacteria, organic wastes, and oil due to the effects of two large habitat disasters: Hurricane Katrina in late August of 2005, and the Deepwater Horizon Oil Spill in April-May, 2010. Another health reason for people to avoid eating oysters and softshell clams is that their meats are commonly fried and are said to contain "hard fats" that some people prefer to avoid. During the 1990's, sales of oysters from Connecticut were slow. Its companies could not sell their entire stocks of market-sized oysters and were seeking markets in Europe with little success. In the mid-1990's, Connecticut oysters were dying from diseases and the problem of limited markets became less of an issue.

In more recent years, the marketing situation regarding oysters has changed sharply. Consumers are now eating far more oysters and most are raw on the half-shell. The implementation of rules developed by the ISSC (Interstate Shellfish Sanitation Conference) issued under strict guidelines, known as the HACCP rules (Hazzard Analysis and Critical Control Points) between January 1997 and January
2000 , has meant that raw oysters have been reasonably safe for people to eat because they are maintained chilled on ice, in many cases from the time they are taken from waters on the decks of harvesting boats, transported in refrigerated trucks, and displayed in market show cases. The rules have allowed science-based testing of oyster and quahog meats for bacteria, including Vibrio parahaemolyticus and other pathogens. Enforcement of the rules by state public health officials has been strict. Associated with this large rise in consumption has been the increase in oyster aquaculture development (hatchery-reared seed and growout beds), and the increased marketing of branded oysters in raw bars and restaurants.

\section{Overview and Assessment of Swings in Bivalve Landings}

The North Atlantic Oscillation, being in a high positive index most of the time during 1980 to 2003, had strong adverse effects on the environments of commercial bivalves in the estuaries and bays of the northeastern U.S. The main effect was the warming of waters during winters. This resulted in poor recruitments of juveniles and bivalve landings falling sharply. In the Wadden Sea, the Netherlands, a series of warm winters in 1988-90 similarly led to a series of low bivalve recruitments (Beukema and Dekker, 2005). Our assessment has found that body weights of bivalves fell as their metabolic rates were relatively high but little food was available to them if they were able to feed. Then in spring and early summer, still less food was available, fewer larvae were produced, substrates for setting larvae declined, predation of juveniles likely increased, diseases of adult oysters increased, and consequently landings became extremely low. The combined landings of the bivalves fell by an estimated $85 \%$.

An extremely poor period for bivalve recruitment occurred during the extra warm 1990's and early 2000's, and most softshell clams were killed in Maryland and New Jersey. After 2003, when the NAO index switched 
to a negative or neutral phase, winters became colder and bivalve recruitment and landings increased at least for oysters in Chesapeake Bay and bay scallops in Massachusetts. Their landings would have been much higher had the substrates (clean oyster shells and eelgrass) for setting larvae been as available as they once had been.

We cannot discount the effects of spring-summer weather on bivalve recruitments. Our undocumented casual observations regarding recruitment successes have suggested that cold snaps that can occur in late springearly summer following temperatures that were rising for a few weeks may interrupt the ripening of the bivalve gonads to the extent that recruitment suffers. In Connecticut, Prytherch (1928) had noted that poor oyster sets resulted when summer temperatures were especially cool. Another adverse factor affecting recruitments in summer is excessively cloudy weather, or when 2-4-day northeasters occur. These probably result in a temporary loss in phytoplankton and a lack of food for larvae and then a weaker recruitment for a brood of larvae. Unusually extended periods of sunny skies may also lead to poorer recruitments.

The magnitudes of bivalve seed produced vary videly among years. Loosanoff $(1965$, 1966) had shown that fecundity and egg production in Connecticut oysters over a 20 -yr period varied somewhat by year, whereas much wider variations occurred in the magnitudes of subsequent spatfalls produced by the oysters. He concluded that survival of the larvae while growing from their straight-hinge stage to metamorphosis and attachments to substrates is extremely small and highly variable among years. Similarly to the bivalves in the Wadden Sea, the stock-recruitment relationship of the bivalves is negative in the northeastern United States. Recruitments of juvenile bivalves bear only a small relationship to the sizes of spawning stocks, except when such stocks become too small. Recruitments of groups of bivalves are affected simi- larly by swings in climate. The swings in their abundances are synchronous in all four species as is true for the magnitudes in bivalve abundances in the Wadden Sea. We have also observed that once each of the bivalves survived beyond its juvenile stage, perhaps to 30-40 mm, its survival to adult stages usually was relatively high.

Studies of finfish suggest that exceptionally large recruitments of marine fish also occur when the timing, species mix, and abundance of early summer blooms fully meet their needs (Beaugrand et al., 2003; Platt et al., 2003; Castonguay et al., 2008). Perhaps the same is true for the bivalves following good spawnings.

Additional types of environmental factors, some related to the NAO, caused declines in the bivalves. Our review of predator feeding rates (Table 11) in the U.S. coastal estuaries and bays also suggests that they became faster, and they could have lasted longer each year due to the higher temperatures and the longer times they remain warm. Besides, the diseases MSX and Dermo became more virulent leading to oyster mortalities increasing sharply in Chesapeake Bay, Delaware Bay, and Long Island Sound (Burreson and Ragone Calvo, 1996; Ford, 1996; Sunila et al., 1999). Blooms of "brown tides," produced by $A$. anophagefferns, that occurred mainly in the three largest lagoons (Great South Bay, Barnegat Bay, and Chincoteague Bay) have prevented survival of bivalve larvae. The partial loss of eelgrass and also some waters becoming eutrophic in Massachusetts and Long Island, N.Y., likely played a large role in the decline of bay scallops. Regarding oysters, looking past factors such as those that are related to the effects resulting from the positive NAO and large silt accumulations on substrates, that both can result in poor recruitments of oysters, we are left mainly with attributing the poor recruitments to their being harvested with dredges that have stripped shells off the bottom. Many bottoms have scattered shells, some of which are decaying or fouled, or exist as small fragments lying on sand sediments.
The oysters, quahogs, softshell clams, and bay scallops in many bays have not been noticeably overfished, certainly since the 1970 's. When bivalve stocks are heavily harvested in beds in state-controlled legal seasons, sufficient numbers of adult bivalves usually will remain to potentially produce large numbers of juveniles on the beds in the following years. The residual stocks remain because by state regulations, fishermen return the undersized bivalves (the seed) that will eventually spawn to the beds. Moreover, fishermen will suspend harvesting if their daily catches become so low they cannot earn adequate money by continuing. The quantities of bivalves that remain have the capacity to produce larvae in large numbers and they could set over wide stretches of bottom if setting substrates were available.

Published and verbal statements commonly related that landings of bivalves have declined since the early 1900 's because they were overfished. For example, most biologists, including Haven et al. (1978) and Hargis and Haven (1988), believed that oysters in Chesapeake Bay must have been overfished because their landings had been falling steadily. Unfortunately, no one then knew about the NAO or its effects on marine life so they could not suggest this as an alternate cause. We have dismissed overfishing of parent stocks as the overriding reason the oysters declined in abundances at various historical times. We suggest that when oysters fell in abundance over time, the cause for them actually was "habitat degradation."

\section{Conclusions and Recommendations}

Loosanoff $(1965,1966)$ and the literature findings we include in this paper show that environmental factors have a dominant role in controlling the magnitudes of commercial bivalve production. The rates of survival and growth to eventual market size of the great many millions of eggs spawned and fertilized vary as the climate and weather vary.

Scattered types of local summer weather affect the successes of bivalve 
recruitments. During periods of calm weather when winds may be blowing gently from the south and southwest, sporadic sharp variations in temperature, wind speed and direction, extent of cloud cover, large storms and heavy rains appear to reduce recruitments. As an example, Prytherch (1928) had observed that poor oyster sets in Connecticut resulted when temperatures were extremely cool. Northeasters, that usually endure for 2-4 days, with winds that blow commonly at 20-30 knots, drive waters containing bivalve larvae in the opposite direction than the gentle winds had been drifting them. The waters that had been calm become rough, bottom materials are stirred into the water and, along with the storm's rains, decaying organic fragments are washed from shore into the water that then becomes highly turbid. A temporary loss of phytoplankton, the food for the larvae, occurs. This may be followed by a weaker recruitment to the bottom for a brood of larvae. How many larvae survive? Are survivors carried to different places where survival will be poor? Will a subsequent brood of larvae be as large and be more successful? Availability of adequate food undoubtedly is a factor with bivalve larvae and also the extent of predation that they suffer explain some of the variability in abundances of bivalve spat.

To an extent, the magnitudes of future recruitments of juvenile bivalves probably will hinge on variations in the NAO index. Their abundances may increase or at least remain stable if its index were to be negative and most winters and springs continued to be relatively cool as most were between 2003 and 2015. The recruitments will likely fall whenever the index is consistently positive.

Winter temperatures appear to be an important factor that controls abundances of many benthic macrofauna also (Oviatt, 2004; Beukema, 1992; Kroncke et al., 1998 Beukema and Dekker, 2014). Their overall species abundances in the 1950's to 1980's probably were different than they were in the 1980 's to 2003 . These macro- fauna have been only weakly surveyed and so comparisons may be difficult to make.

Upon discovering that comparisons of the winter (December-April) status of the NAO index and finfish recruitments can be close (Dippner, 1997), Brander and Mohn (2004), and Alheit et al. (2005) in European waters, and Kimmel et al. (2009) in Chesapeake Bay, and Aburto-Oropeza et al. (2010) in California suggest that predictions about fish recruitments could be made by determining the NAO index during winters. Such tracking might also be applied to bivalves in northeastern U.S. bay waters. Since swings in the NAO indices have effects on several components of ecosystems, Kimmel et al. (2009) suggest that researchers and resource managers could examine appropriate components, such as temperature and abundances of copepods and ctenophores, in local waters to help them make forecasts. Myers (1998), though, cautions that such relationships are often not useful because the NAO and the weather can be unstable.

The effects of shrimp predation on the recruits of bivalves and other biota need more attention, following the research studies conducted by Beukema (1993) in Europe and MacKenzie and Lind (2013) in Massachusetts. We also encourage studies be undertaken to examine the effects of copepod feeding on phytoplankton and its consequences, using the Narragansett Bay studies as examples. Can we take constructive steps to improve environments for commercial bivalves to enable them to become more abundant? Oysters would become more abundant if more substrate material (shells) for their larvae was added to setting beds. Additional study could be made of the effects of overgrowth of the alga Gracilaria spp. over eelgrass meadows. Some curtailment of eutrophication in waters so polluted might allow the bivalve abundances to increase.

Heretofore, landing declines of bivalve mollusks usually have been ascribed to overfishing. This paper has been prepared as part of an attempt to understand the true causes of the de- clines. Future actions to manage these bivalves for societal benefit will be more effective as these causes become understood.

\section{Acknowledgments}

We thank J. Urban-Rich and her three University of Massachusetts students for providing help during field observations, and P. Bagnall, P. Boyce, M. H. Cormier, W. Gaines, I. Perry, T. Riley, and G. Sherman for their generous help with making field observations. M. Southworth kindly provided historical oyster setting data from Virginia locations, and M. Hickey and R. Rheault provided information about the history of the ISSC and HCCP. J. J. Beukema, L.-A. Davidson, V. G. Guida, C. Oviatt, and J. B. Pearce made constructive comments on earlier drafts of the manuscript. As the concept of this manuscript was being developed, ideas from J. A. Francis, R. W. Langton, and R. E. Taylor contributed to its contents.

\section{Literature Cited}

Aburto-Oropeza, O., G. Paredes, I. Mascare asOsorio, and E. Sala. 2010. Climatic influence on reef fish recruitment and fisheries. Mar. Ecol. Prog. Ser. 410:283-287. (doi: https:// doi.org/10.3354/meps08695).

Alheit, J., C. Mollmann, J. Dutz, C. Kornilovs, P. Loewe, V. Mohrholz, and M. Wasmund. 2005. Synchronous ecological regime shifts in the central Baltic and the North Sea in the late 1980s. ICES J. Mar. Sci. 62:12051215. (doi: https://doi.org/10.1016/j.icesjms. 2005.04.024).

Anderson, R. S., B. S. Kraus, S. McGladdery, and R. Smolowitz. 2003. QPX, a pathogen of quahogs (hard clams), employs mucoid scretions to resist host antimicrocial agents. J. Shellf. Res. 22(1):205-208.

Andrews, J. D., J. L. Wood, and H. D. Hoese. 1962. Oyster mortality studies in Virginia. III. Epizootiology of a disease caused by Halosporidium costale. Wood and Andrew. J. Insect Pathol. 4:327-343.

Anonymous. 1908. A successful organization of oyster growers. Fishing Gaz. 9 May. 25(19):530.

1911. The oyster Ass'n of North America: has it done its work? Fishing Gaz. 22 July 28(29).

Attrill, M. J., and M. Power. 2002. Climatic influence on a marine fish assemblage. Nature 417:275-278. (doi: https://doi.org/10.1038/ 417275a)

Baez, J. C., J. J. Bellido, F. Ferri-Yanez, J. J. Castillo, and J. J. Martin. 2011. The North Atlantic Oscillation and sea surface temperature affect loggerhead abundance around the Strait of Gibraltar. Scientia Marina (Barcelona) 75(3):571-575. (doi: https://doi.org/10.3989/ scimar.2011.75n3571). 
Belding, D. L. 1910. A report upon the scallop fishery of Massachusetts, including the habits, life history of Pecten irradians, its rate of growth, and other facts of economic value. Wright Potter Print. Co., State Print., Boston, $150 \mathrm{p}$.

Beaugrand, G., and P. C. Reid. 2003. Longterm changes in phytoplankton, zooplankton and salmon related to climate. Global Change Biol. 9:801-817. (doi: https://doi.org/ 10.1046/j.1365-2486.2003.00632.x).

P. C. Reid, F. Ibañez, J. A. Lind-

ley, and M. Edwards. 2002. Reorganization of North Atlantic marine copepod biodiversity and climate. Science 296 (5573):1,6921,694. (doi: https://doi.org/10.1126/science. 1071329).

K. M. Brander, J. A. Lindley, S.

Souissi, and P. C. Reid. 2003. Plankton effect on cod recruitment in the North Sea. Nature 426:661-664. (doi: https://doi.org/10.1038/ nature02164).

Beukema, J. J. 1991. The abundance of shore crabs Carcinus maenas (L.) on a tidal flat in the Wadden Sea after cold and mild winters. J. Exp. Mar. Biol. Ecol. 153:97-113. (doi: https://doi.org/10.1016/ S0022-0981(05)80009-7).

1992. Expected changes in the Wadden Sea benthos in a warmer world: lessons from periods with mild winters. Neth. J. Sea Res. 30:73-79. (doi: https://doi. org/10.1016/0077-7579(92)90047-I).

1993. Increased mortality in alternative bivalve prey during a period when the tidal flats of the Dutch Wadden Sea were devoid of mussels. Neth. J. Sea Res. 31:395-406. (doi: https://doi.org/10. 1016/0077-7579(93)90056-X).

and R. Dekker. 2005. Decline of recruitment success in cockles and other bivalves in the Wadden Sea: possible role of climate change, predation on postlarvae and fisheries. Mar. Ecol. Prog. Ser. 287:149-167. (doi: https://doi.org/10.3354/meps287149). and 2014. Variability

in predator abundance links winter temperatures and bivalve recruitment: correlative evidence from long-term data in a tidal flat. Mar. Ecol. Prog. Ser. 513:1-15. (doi: https://doi. org/10.3354/meps10978). and C. J. M. Philippart. 2010.

Long-term variability in bivalve recruitment, mortality, and growth, and their contribution to fluctuations in food stocks of shellfish-eating birds. Mar. Ecol. Prog. Ser. 414:117-130. (doi: https://doi.org/10.3354/meps08706).

, P. J. C. Honkoop, and R. Dekker.

1998. Recruitment in Macoma balthica after mild and cold winters and its possible control by egg production and shrimp predation. Hydrobiologia 375/376:23-34.

R. Dekker, and J. M. Jansen. 2009.

Some like it cold: populations of the tellinid bivalve Macoma balthica (L.) suffer in various ways from a warming climate. Mar. Ecol. Progr. Ser. 384:135-145. (doi: https://doi. org/10.3354/meps07952).

Bindoff, N. J., J. Willebrand, V. Artile, A. Cazenave, J. Gregory, S. Gulkev, and K. Hanawa. 2007. Observation: ocean climate change and sea level. In S. Solomon et al. (Editors), Chapter 5 in Climate Change 2007. The physical science basis: Contrib. WGI to Fourth Assessment Rep. Intergov. Panel on Climate Change. Camb. Univ. Press. Cambridge, UK.
Bintz, J. C., S. W. Nixon, B. A. Buckely, and S L. Granger. 2003. Impacts of temperature and nutrients on coastal lagoon plant communities. Estuaries 26(3):765-776.

Black, J. A., and J. Kassner. 1988. Small forms and brown tides. The Dolphin, p. 4-5.

Boesch, D. F., E. Burreson, W. Dennison, E. Houde, M. Kemp, V. Kennedy, R. Newell, K. Paynter, R. Orth, R. Ulanowicz, C. Peterson, J. Jackson, M. Kirby, H. Lenihan, B. Bourque, R. Bradbury, R. Cooke, S. Kidwell. 2001. Factors in the decline of coastal ecosystems. Science 293:1,589-1,591.

Boynton, W. R., J. D. Hagy, L. Murray, C. Stokes, and W. M. Kemp. 1996. Comparative analysis of eutrophication patterns in a temperate coastal lagoon. Estuaries 19(28):408-421.

Brander, K., and R. Mohn. 2004. Effect of the North Atlantic Oscillation on recruitment of Atlantic cod (Gadus morhua). Can. J. Fish. Aquat. Sci 63:1,158-1,564. (doi: https://doi. org/10.1139/f04-087).

Brandt, G., A. Wehrmann, and K. W. Wirtz. 2008. Rapid invasion of Crassostrea gigas into the German Wadden Sea dominated by larval supply. J. Sea Res. 59(4):279-296. (doi: https://doi.org/10.1016/j.seares.2008.03.004).

Bricelj, V. M. and D. J. Lonsdale. 1997. Aureococcus anophagefferens: causes and ecological consequences of brown tides in U.S. mid-Atlantic coastal water. Limnol. Oceanogr. 42:1,023-1,038. (doi: https://doi. org/10.4319/lo.1997.42.5_part_2.1023). and S. MacQuarrie. 2007. Effects

of brown tide (Aureococcus anophagefferens) on hard clam Mercenaria mercenaria larvae and implications for benthic recruitment. Mar. Ecol. Prog. Ser. 331:147-159. (doi: https://doi.org/10.3354/meps331147).

Bundesen, H. N. 1925. Typhoid epidemic in Chicago apparently due to oysters. JAMA 84(9):641-650. (doi: https://doi.org/10.1001/ jama.1925.02660350005002

Burrell, V. G., Jr., and W. A. Van Engle. 1976. Predation by and distribution of a ctenophore, Mnemiopsis leidyi A. Agassiz, in the York River, Estuary. Estuar. Coast. Mar. Sci. 4:235-242.

Burreson, E. M., and L. M. Ragone Calvo. 1996. Epizootiology of Perkinsus marinus disease of oysters in the Chesapeake Bay, with emphasis on datra since 1985. J. Shellfish Res. 15:17-34.

Bushek, D., S. E. Ford, and I. Burt. 2012. Longterm patterns of an estuarine pathogen along a salinity gradient. J. Mar. Res. 70:225-251.

Caceres-Martinez, J., and A. Figueras. 1997 The mussel, oyster, clam, and pectinid fisheries of Spain. In C. L. MacKenzie, Jr., V. G. Burrell, Jr., A. Rosenfield, and W. L. Hobart (Editors), The history, present condition, and future of the molluscan fisheries of North and Central America and Europe, Vol. 3, Europe, p. 165-190. U.S. Dep. Commer, NOAA Tech. Rep. NMFS 129.

Carmichael, R. H., A. C. Shriver, and I. Valiela. 2004. Changes in shell and soft tissue growth, tissue composition, and survival of quahogs, Mercenaria mercenaria, and softshell clams, Mya arenaria, in response to eutrophic-driven changes in food supply and habitat. J. Exp. Mar. Biol. Ecol. 313:75-104. (doi: https:// doi.org/10.1016/j.jembe.2004.08.006).

Carriker, M. R. 1957. Preliminary study of behavior of newly hatched oyster drills, Uro- salpinx cinerea (Say). J. Elisha Mitchell Sci. Soc., 73:328-351.

Castonguay, M., S. Plourde, D. Robert, J. A. Ringe, and L. Fortier. 2008. Copepod production drives recruitment in a marine fish. Can J. Fish. Aquat. Sci. 65(8):1,528-1,531. (doi: https://doi.org/10.1139/F08-126).

Churchill, E. P., Jr. 1911. The oyster and the oyster industry of the Atlantic and Gulf coasts. Rep. U.S. Comm. Fish. For fiscal year 1919. Gov. Print. Off., Wash., D.C., 51 p.

Cloem, J. 2001. Our evolving conceptual model of the costal eutrophication problem. Mar. Ecol. Prog. Ser. 210:223-252. (doi: https:// doi.org/10.3354/meps210223).

Collie, J. S., A. D. Wood, and H. P. Jeffries. 2008. Long-term shifts in the species composition of a coastal fish community. Can J. Fish and Aquat. Sci. 1,352-1,365. (doi https://doi.org/10.1139/F08-048).

Compton, T. J., T. A. Troost, J. Drent, C. Kraan, P. Bocher, J. Leyrer, A. Dekinga, and T. Piersma. 2009. Repeatable sediment associations of burrowing bivalves across six European tidal flat systems. Mar. Ecol. Prog. Ser. 382:87-98. (doi: https://doi.org/10.3354) meps07964

Cook, T., M. Folli, J. Klinck, S. Ford, and J. Miller. 1998. The relationship between increasing sea surface temperature and the spread of Perkinsus marinus (Dermo) disease epizootics in oysters. Estuar. Coast Shelf. Sci. 46:587-597. (doi: https://doi.org/10.1006/ ecss.1997.0283).

Crossett, K. M., T. J. Culliton, P. C. Wiley, and T. R. Goodspeed. 2004. Population by coastal watershed. In Population trends along the coastal United States: 1980-2008, p. 24-25. Coastal Trends Rep. Ser., U.S. Dep. Commer., NOAA, Natl. Ocean Serv. and U.S. Census Bur.

Dedah, C., W. R. Keithly, Jr., and R. F. Kazmierczak, Jr. 2011. An analysis of US oyster demand and the influence of labeling requirements. Mar. Res. Econ. 26:17-33. (doi: https://doi.org/10.5950/0738-1360-26.1.17).

Dekker, R., and J. J. Beukema. 2014. Phenology of abundance of bivalve spat and of their epibenthic predators: limited evidence for mismatches after cold winters. Mar. Ecol. Prog. Ser. 513:17-27. (doi: https://doi.org/10.3354/ meps10989).

Dijkema, R. 1997. Molluscan fisheries and culture in the Netherlands. 1997. In C. L. MacKenzie, Jr., V. G. Burrell, Jr., A. Rosenfield, and W. L. Hobart (Editors), The history, present condition, and future of the molluscan fisheries of North and Central America and Europe, Volume 3, Europe, p. 115-135. U.S. Dep. Commer., NOAA Tech. Rep. NMFS 129

Dippner, J. W. 1997. Recruitment success of different fish stocks in the North Sea in relation to climate variability. German J. Hydrogr. 49(2-3):277-293

Dove, A. D. M., P. R. Bowser, and R. M. Cerato. 2004. Histological analysis of an outbreak of QPX disease in wild hard clams Mercenaria mercenaria in New York. J. Aquat. Animal Health 16:246-250. (doi: https://doi. org/10.1577/H03-052.1).

Eckman, J. E., C. H. Peterson, and J. A. Cahalan. 1989. Effects of flow speed, turbulence and orientation on growth of juvenile bay scallops, Argopecten irradians concentricus (Say). J. 
Exp. Mar. Ecol. 132:13-140. (doi: https://doi. org/10.1016/0022-0981(89)90219-0).

Edwards, E. 1997. Molluscan fisheries in Britain. In C. L. MacKenzie, Jr., V. G. Burrell, Jr., A. Rosenfield, and W. L. Hobart (Editors), The history, present condition, and future of the molluscan fisheries of North and Central American and Europe. Vol. 3, Europe, p. 8599. U. S. Dep. Commer. NOAA Tech. Rep. NMFS 129.

Edwards, M., P. Reid, and B. Planque. 2001. Long term regional variability of phytoplankton biomass in the Northeast Atlantic (19601995). ICES J. Mar. Sci. 58:39-49. (doi: https://doi.org/10.1006/jmsc.2000.0987).

Fishery Statistics of the United States 1970. 1973. Statistical Digest 64. NMFS. U.S. Gov't Print Off., Wash. D.C., 489 p.

Fonseca, M. S., and J. A. Cahalan. 1992. A preliminary evaluation of wave attenuation by four species of seagrass. Estuar. Coast. Shelf Sci. 35(6):565-576.

and A. V. Uhrin. 2009. The status of eelgrass, Zostera marina, as bay scallop habitat: Consequences for the fishery in the western Atlantic. Mar. Fish. Rev. 71(3):20-33.

J. C. Zieman, G. W. Thayer, and J. S. Fisher. 1983. The role of current velocity in structuring eelgrass (Zostera marina L.) meadows. Estuar. Coast. Shelf Sci. 17(4):367-380. (doi: https://doi. org/10.1016/0272-7714(83)90123-3).

Ford, S. E. 1996. Range extension by the oyster parasite Perkinsus marinus into the northeastern United States: Response to climate change? J. Shellfish Res. 15(1):45-56.

1997. History and present status of molluscan shellfisheries from Barnegat Bay to Delaware Bay. In C. L. MacKenzie, Jr., V. G. Burrell, Jr., A. Rosenfield, and W. L. Hobart (Editors), History, present condition, and future of the molluscan fisheries of North and Central America, and Europe, Vol. 1, Atlantic and Gulf Coasts, p. 119-140. U.S. Dep. Commer., NOAA Tech. Rep. NMFS 127.

and H. H. Haskin. 1982. History and epizootiology of Haplosporidium nelsoni (MSX), an oyster pathogen, in Delaware Bay, 1957-1980. J. Invertebr. Pathol. 40:118-141. (doi: https://doi. org/10.1016/0022-2011(82)90043-X). and M. R. Tripp. 1996. Diseases and defense mechanisms. In V. S. Kennedy, R. I. E. Newell, and A. F. Newell (Editors), The eastern oyster Crassostrea virginica, $\mathrm{p}$. 581-660. Maryland Sea Grant, Coll. Park, MD

Fox, S. E., E. Stieve, J. Valiela, J. Hauxwell, and J. McClelland. 2008. Macrophyte abundance in Waquoit Bay. Effects of land-derived nitrogen loads on seasonal and multi-year biomass. Estuar. Coasts 31(3):532-541. (doi: https://doi.org/10.1007/s12237-008-9039-6).

Fransz, H. G., and W. W. C. Gieskes. 1984. The unbalance of phytoplankton and copepods in the North Sea. Rapp. P.-v. Réun. Cons. Int. Explor. Mer. 183:218-225.

Galtsoff, P. S., and V. L. Loosanoff. 1939. Natural history and method of controlling the starfish (Asterias forbesi, Desor). Bull. Bur. Fish. 49(31):75-132

Goulletquer, P., and M. Heral. 1997. Marine molluscan production trends in France: from fisheries to aquaculture. In C. L. MacKenzie, Jr., V. G. Burrell, Jr., A. Rosenfield, and W. L. Hobart (Editors), The history present condi- tion, and future of the molluscan fisheries of North and Central America and Europe, Vol. 3, Europe, p. 137-164. U. S. Dep. Commer., NOAA Tech. Rep. NMFS 129.

Grosslein, L. A., and P.-Y. Qian. 1997. Juvenile mortality in benthic marine invertebrates. Mar. Ecol. Prog. Ser. 146:265-282. (doi: https://doi.org/10.3354/meps146265).

Hammer, J. 1997. The mussel industry of Sweden. In C. L. MacKenzie, Jr., V. G. Burrell, Jr., A. Rosenfield, and W. L. Hobart (Editors), The history, present condition, and future of the molluscan fisheries of North and Central America and Europe, Vol. 1, Europe, p. 1-6. U. S. Dep. Commer., NOAA Tech. Rep. NMFS 129.

Hanks, J. E. 1952. The effects of changes in water temperature and salinity on the feeding habits of the boring snails, Polinices heros and Polinices duplicata. Fifth report on investigations of the shellfisheries of Massachusetts. Dep. Conserv., Div. Mar. Fish. Commonw. Mass., p. 33-37.

Hanson, A. R. (Editor). 2004. Status and conservation of eelgrass (Zostera marina) in Eastern Canada. Can. Wildl. Serv. Atl. Reg., Tech. Rep. Ser. 41, 40 p.

Harding L. W., Jr. 1994. Long-term trends in the distribution of phytoplankton in Chesapeake Bay: roles of light, nutrients and streamflow. Mar. Ecol. Prog. Ser. 104:267-291

Hare, J. A., and K. W. Able. 2006. Mechanistic links between climate and fisheries along the east coast of the United States: explaining population outbursts of Atlantic croaker (Micropogonias undulatus). Fish. Oceanogr. 16(1):31-45. (doi: https://doi. org/10.1111/j.1365-2419.2006.00407.x).

Hargis, W. J., Jr., and D. C. Haven. 1988. The imperiled oyster industry of Virginia. Va. Inst. Mar. Sci., Spec. Rep. Appl. Mar. Sci. Ocean Engr. 290, $130 \mathrm{p}$.

Harvell, D. C., C. E. Mitchell, J. R. Ward, S. Altizer, A. Dobson, R. G. Osfeld, and M. D. Samuel. 2002. Climate warming and disease risks for terrestrial and marine biota. Science 296:2,158-2,162. (doi: https://doi. org/10.1126/science.1063699).

Haskin, H. H., and S. Tweed. 1976. Oyster setting and early spat survival at critical salinity levels on natural seed oyster beds of Delaware Bay. Water Resour. Inst., Rutgers Univ., New Brunswick, N.J., 66 p.

L. A. Stauber, and J. A. Mackin. 1966. Minchinia nelsoni sp. n. (Haplosporida, Haplosporidiidae): causative agent of the Delaware Bay oyster epizootic. Science 153:1,414-1,416. (doi: https://doi. org/10.1126/science.153.3742.1414).

Hauxwell, J., J. Cebrian, and I. Valiela. 2003. Eelgrass Zostera marina loss in temperate estuaries: relationship to land-derived nitrogen loads and effect of light limitation imposed by algae. Mar. Ecol. Prog. Ser. 247:59-73. (doi: https://doi.org/10.3354/meps247059).

Haven, D. S., W. J. Hargis, Jr., and P. C. Kendall. 1978. The oyster industry of Virginia: its status, problems and promise. Va. Inst. Mar. Sci., Spec. Pap. Mar. Sci. 4, 1,024 p.

Heck, K. L., and R. J. Orth. 1980. Structural components of eelgrass (Zostera marina) meadows in the lower Chesapeake Bay-decapod crustacea. Estuaries 3(4):289-295. (doi: https://doi.org/10.2307/1352084).

Henderson, P. A., and R. M. Seaby. 2005. The role of climate in determining the tem- poral variation in abundance, recruitment and growth of sole Solea solea in the Bristol Channel. J. Mar. Biol. Assoc. U.K. 85:197-204. (doi: https://doi.org/10.1017/ S0025315405011069h)

Honkoop, P. J. C., and J. J. Beukema. 1997. Loss of body mass in winter in three intertidal bivalve species: an experimental and observational study of the interacting effects between water temperature, feeding time and feeding behaviour. J. Exp. Mar. Biol. Ecol 212:277-297. (doi: https://doi.org/10.1016/ S0022-0981(96)02757-8).

and J. van der Meer. 1997. Reproductive output of Macoma balthica populations in relation to winter-temperature and intertidal-height mediated changes of body mass. Mar. Ecol. Prog. Ser. 149:155-162. (doi: https://doi.org/10.3354/meps149155). and 1998. Experimentally induced effects of water temperature and immersion time on reproductive output of bivalves in the Wadden Sea. J. Exp. Mar. Biol. Ecol. 220(2):227-246. (doi: https://doi. org/10.1016/S0022-0981(97)00107-X).

J. J. Beukema, and

D. Kwast. 1998. Does temperature-influenced egg production predict the recruitmen in the bivalve Macoma balthica? Mar. Ecol. Progr. Ser. 164:229-235. (doi: https://doi. org/10.3354/meps164229).

Howarth, R. W., A. Sharpley, and D. Walker 2002. Sources of nutrient pollution to coastal waters in the United States: implications for achieving coastal water quality goals. Estuaries 25(4):656-676. (doi: https://doi. org/10.1007/BF02804898)

Hurrell, J. W. 1995. Decadal trends in the North Atlantic Oscillation: regional temperatures and precipitation. Science 269:676-679. (doi: https://doi.org/10.1126/ science.269.5224.676).

and C. Deser. 2009. North Atlantic climate variability: The role of the North Atlantic Oscillation. J. Mar. Systems 78(1):28-41. (doi: https://doi.org/10.1016/j. jmarsys.2008.11.026)

and H. van Loon. 1997. Decadal variations in climate associated with the North Atlantic Oscillation. Climate Change 36:301-326. (doi: https://doi. org/10.1023/A:1005314315270).

Y. Kashmir, G. Ottersen, and M. Visbeck. 2003. The North Atlantic Oscillation: climate significance and environmental impact. Geophys. Monogr. 134, 35 p. Am. Geophys. Union (doi: https://doi.org/10.1029 GM134).

Ingersoll, E. 1881. The oyster industry. In G. B. Goode (Editor), The history and present condition of the fishery industries. U.S. Gov. Print Off., Wash., D.C , 251 p., U.S. Comm. Fish Fish. Wash., D.C

1887. The oyster, scallop, quahog, mussel, and abalone industries. In G.B. Goode (Editor), The fisheries and fishery industries of the United States, Sec. II, p. 507626. U.S. Comm. Fish Fish., Wash., D.C.

Irigolen, X., R. P. Harris, R. N. Head, and D. Harbor. 2000. North Atlantic Oscillation and spring bloom phytoplankton composition in the English Channel. J. Plankton Res. 22(12):2,367-2,371. (doi: https://doi. org/10.1093/plankt/22.12.2367).

Jansen, J. M., A. E. Pronker, S. Wendelaar Bonga, and H. Hummel. 2007. Macoma balth- 
ica in Spain, a few decades back in history. J. Exp. Mar. Biol. Ecol. 344:161-169. (doi: https://doi.org/10.1016/j.jembe.2006.12.014).

Jeffries, H. P., and M. Terceiro. 1985. Cycle of changing abundances in the fishes of the Narragansett Bay area. Mar. Ecol. Prog. Ser. 25:239-244.

Jenkins, J. B., A. Morrison, and C. L. MacKenzie, Jr. 1997. The molluscan fisheries of the Canadian Maritmes. In C. L. MacKenzie, Jr., V. G. Burrell, Jr. A. Rosenfield, and W. L. Hobart (Editors), The history, present condition, and future of the molluscan fisheries of North and Central America and Europe, Volume 1. Atlantic and Gulf Coasts, p. 15-44. U.S. Dep. Commer., NOAA Tech. Rep. 127.

Keller, A. A., and G. Klein-MacPhee. 2000. Impact of elevated temperature on the growth, survival, and trophic dynamics of winter flounder larvae: A mesocosm study. Can. J. Fish. Aquat. Sci. 57:2,382-2,392. (doi: https://doi.org/10.1139/f00-217).

C. A. Oviatt, H. A. Walker, and J.

D. Hawk. 1999. Predicted impacts of elevated temperature on the magnitude of the winterspring phytoplankton bloom in temperate coastal waters: a mesocosm study. Limnol. Oceanogr. 44(2):344-356. (doi: https://doi. org/10.4319/1o.1999.44.2.0344).

C. Taylor, C. Oviatt, T. Dorrington, G. Holcombe, and L. Reed. 2001. Phytoplankton production patterns in Massachusetts Bay and the absence of the 1998 winter-spring bloom. Mar. Biol. 138:1051-1062. (doi: https://doi.org/10.1007/ s002270000525)

Kemp, W. M., W. R. Bornton, J. E. Adolf, D. F. Boesch, W. C. Boicourt, G. Bush, J. C. Cornwell, T. R. Fisher, P. M. Gilbert, J. D. Hagy, L. W. Harding, E. D. Houde, D. G. Kimmel, W. D. Miller, R. I. E. Newell, M. R. Roman, E. M. Smith, and J. C. Stevenson. 2005. Eutrophication of Chesapeake Bay: historical trends and ecological interactions. Mar. Ecol. Prog. Ser. 303:1-29. (doi: https://doi. org/10.3354/meps303001)

Kennish, M. J. 2001. Physical description of the Barnegat Bay-Little Egg Harbor estuarine system. In Barnegat Bay-Little Egg Harbor, New Jersey: estuary and watershed assessment. J. Coast. Res. 32:13-27.

S. B. Bricker, W. C. Dennison, P.

M. Glibert, R. J. Livingston, K. A. Moore, R. T. Noble, H. W. Paerl, J. M. Ramstack, S. Seitzinger, D. A. Tomasko, and I. Valiela. 2007. Barnegat Bay-Little Egg Harbor estuary: case study of a highly eutrophic coastal bay system. In M. J. Kennish and A. R. Townsend (Editors), Nutrient enrichment and estuarine eutrophication, p. 53-516. Ecol. Appl. 17. (doi: https://doi. org/10.1890/05-0800.1).

M. Haag, and G. P. Sakowicz. 2010. Seagrass decline in New Jersey coastal lagoons: A response to increasing eutrophication. In M. J. Kennish and H. W. Pearl (Editors), Coastal Lagoons: critical habitats of environmental change, p. 167-201, Taylor and Francis, CRC Press, Boca Raton, Fla.

B. Fertig, G. P. Sakowicz, and G. Petruzzelli. 2013. Loss of eelgrass in the Barnegat Bay-Little Egg Harbor Estuary, New Jersey (Abstr.). In Mid-Atlantic Chapt. Am. Fish. Soc., 2013 Ann. Meet. Program, Tuckerton, N.J.
Keus, B. 1986. De predatie van de garnaal (Crangon crangon) op het broed van het nonnetje (Macoma balthica). Interne Verslagen Nederl. . Inst. Onderz. Zee, 1895-6. Texel: $1-43$.

Kimmel, D. G., W. D. Miller, L. W. Harding, Jr., E. D. Houde, and M. R. Roman. 2009. Estuarine ecosystem response captured using a synoptic climatology. Estuar. Coasts. 32:403-409. (doi: https://doi.org/10.1007/ s12237-009-9147-y).

Kirby, R. R., G. Beaugrand, J. A. Lindley, A J. Richardson, M. Edwards, and P. C. Reid. 2007. Climate effects and benthic-pelagic coupling in the North Sea. Mar. Ecol. Prog. Ser. 330:31-38. (doi: https://doi.org/10.3354/ meps330031)

2008. Climate-induced effects on the meroplankton and the benthic-pelagic ecology of the North Sea. Limnol. Oceanogr. 53(5):1805-1815. (doi: https://doi.org/10. 4319/1o.2008.53.5.1805)

2009. Synergistic effects of climate and fishing in a marine ecosystem. Ecosystems 12:548-561. (doi: https://doi.org/10.1007/ s10021-009-9241-9).

Kochiss, J. M. 1974. Oystering from New York to Boston. Wesleyan Univ. Press, Middletown, Conn., $251 \mathrm{p}$.

Kraeuter, J. N. 2001. Predators and predation. In J. N. Kraeuter and M. Castagna (Editors), Biology of the hard clam, p. 441-589. Elsevier, Develop. Aquacult. Fish. Sci. 31.

Kristensen, P. S. 1997. Oyster and mussel fisheries in Denmark. In C. L. MacKenzie, Jr., V. G. Burrell, Jr., A. Rosenfield, and W. L. Hobart (Editors), The history, present condition, and future of the molluscan fisheries of North and Central America and Europe. Vol. 3, Europe, p. 25-56. U. S. Dep. Commer. NOAA Tech. Rep. NMFS 129

Kroncke, I., J. W. Dippner, H. Heyen, and B. Zeiss. 1998. Long-term changes in macrofaunal communities off Norderney (East Frisia, Germany) in relation to climate variability. Mar. Ecol. Prog. Ser. 167:25-36. (doi: https:// doi.org/10.3354/meps167025).

Kulp, R. E., V. Politano, H. A. Lane, S. A. Lombardi, and K. T. Paynter. 2011. Predation of juvenile Crassostrea virginica by two species of mud crabs found in Chesapeake Bay. J. Shellfish Res. 30(2):261-266. (doi: https:// doi.org/10.2983/035.030.0210).

Landers, W. S., and E. W. Rhodes. 1970. Some factors influencing predation by the flatworm, Stylochus ellipticus (Girard), on oysters. Chesapeake Sci. 11:55-60. (doi: https://doi. org/10.2307/1351343)

Lee, W. M. 1914. How to improve the oyster industry in Virginia. Fish. Gaz. 31:577-579.

Li, Y., and T. J. Smayda. 1998. Temporal variability of chlorophyll in Narragansett Bay, 19731990. ICES J. Mar. Sci. 55:661-667. (doi: https://doi.org/10.1006/jmsc.1998.0383).

Loosanoff, V. L. 1965. Gonad development and discharge of spawn in oysters of Long Island Sound. Biol. Bull. 129(3):546-561. (doi: https://doi.org/10.2307/1539732). 1966. Time and intensity of setting of the oyster, Crassostrea virginica, in Long Island Sound. Biol. Bull. 130(2):211-227. (doi: https://doi.org/10.2307/1539698). and C. A. Nomejko. 1956. Relative

intensity of oyster setting in different years in the same areas of Long Island Sound Biol. Bull. 111(3):387-392. (doi: https://doi. org/10.2307/1539145).

Lyles, C. H. 1969. Historical catch statistics (shellfish). U.S. Dep. Inter., Fish Wildl. Serv., Curr. Fish Stat. 5007, 116 p.

Lynam, C. P., S. J. Hay, and A. S. Brierley. 2004. Interannual variability in abundance of North Sea jellyfish and links to the North Atlantic Oscillation. Limnol. Oceanogr 49(3):637-643. (doi: https://doi.org/10.4319/ 1o.2004.49.3.0637)

Lyons, M. M., R. Smolowitz, M. GomezChiarri, and J. E. Ward. 2007. Epizootiology of quahogs parasite unknown (QPX) disease on northern quahogs (=hard clams) Mercenaria mercenaria. J. Shellfish Res. 26:371-381. (doi: https://doi.org/ 10.2983/0730-8000(2007)26[371:EOQPUQ] 2.0.CO;2).

MacKenzie, C. L., Jr. 1977. Sea anemone predation of larval oysters in Chesapeake Bay (Maryland). Proc. Natl. Shellf. Assoc. 67:113-117.

1981. Biotic potential and environmental resistance in the American oyste (Crassostrea virginica) in Long Island Sound. Aquaculture 22:229-268. (doi: https://doi. org/10.1016/0044-8486(81)90151-4).

1983. To increase oyster production in the northeastern United States. Mar. Fish. Rev. 45(3):1-22.

1992. The fisheries of Raritan Bay. Rutgers Univ Press, New Brunswick, N.J., $304 \mathrm{p}$.

1996. History of oystering in the United States and Canada, featuring the eight greatest oyster estuaries. Mar. Fish. Rev. 58(4):1-78

2007. Causes underlying the historical decline in eastern oyster (Gmelin, 1791) landings. J. Shellfish Res. 26:927938. (doi: https://doi.org/10.2983/0730-8000 (2007)26[927:CUTHDI]2.0.CO;2)

and H. Lind. 2013. Shrimp and small fishes as predators in eelgrass meadows. Underwater Naturalist. Bull. Am. Littoral Soc. 29(1):10-14.

and S. M. McLaughlin. 2000. Life

history and habitat observations of softshell clams Mya arenaria in northeastern New Jersey. J. Shellf. Res. 19(1):35-41.

and R. Pikanowski. 2004. Gear effects on marine habitats: Harvesting northern quahogs in a shallow sandy bed at two levels of intensity with a short rake. N. Am. J. Fish. Manage. 24(4):1221-1227. (doi: https://doi. org/10.1577/M03-127.1)

D. J. Radosh, and R. N. Reid. 1985. Densities, growth, and mortalities of juveniles of the surf clam (Spisula sollidis sima) (Dillwyn) in the New York Bight. J. Shellf. Res. 5:81-84.

A. Morrison, D. L. Taylor, V. G. Burrell, Jr., W. S. Arnold, and A. T. WakidaKusunoki. 2002. Quahogs in eastern North America: part I, biology, ecology, and historical uses. Mar. Fish Rev. 64(2):1-55.

R. Pikanowski, and D. G. McMillan. 2006. Ampelisca amphipod tubes may enhance abundance of northern quahogs $\mathrm{Mer}$ cenaria mercenaria in muddy sediments. J. Shellfish Res. 25(3):841-847.

Manzi, J. J. 1970. Combined effects of salinity and temperature on the feeding, reproductive and survival rates of Eupleura caudate 
(Say) and Urosalpinx cinerea (Say) (Prosobranchia:Muricidae). Biol. Bull. 138:75-45. (doi: https://doi.org/10.2307. 1540289).

Marcus, N. 2004. An overview of the impacts of eutrophication and chemical pollutants on copepods of the coastal zone. Zool. Stud. 43(2):211-217.

Marshall, N. 1947. An abundance of bay scallops in the absence of eelgrass. Ecol. Soc. Am. 28:321-322. (doi: https://doi. org/10.2307/1930521).

Marshall, J., Y. Kushnir, D. Battisti, P. Chang, A. Czaja, R. Dickson, J. Hurrell, M. McCartney, R. Saravanan, and M. Visbeck. 2001. North Atlantic climate variability: phenomena, impacts and mechanisms. Int. J. Climatol. 21:1863-1898.

Martens, P. 2001. Effects of the severe winter of 1995/96 on the biological oceanography of the Sylt-Rømø tidal basin. Helgol. Mar. Res. 55:166-169.

McCay, B. J., and W. P. Jenks, III. 1997. The importance of shellfisheries to coastal communities. In C. L. MacKenzie, Jr., V. G. Burrell, Jr., A. Rosenfield, and W. L. Hobart (Editors), The history, present condition, and future of the molluscan fisheries of North and Central America and Europe, p. 145-155, Vol. 2, Pacific coast and supplemental topics. U.S. Dep. Commer., NOAA Tech. Rep. NMFS 128.

McNamara, M. E., D. J. Lonsdale, and R. M. Cerrato. 2010. Shifting abundance of the Ctenophore Mnemiopsis leidyi and the implications for larval mortality. Mar. Biol. 157:401-412. (doi: https://doi.org/10.1007/ s00227-009-1327-6)

Moore, H. F. 1911. Condition and extent of the natural oyster beds of Delaware. U.S. Bur. Fish. Doc. 745. U.S. Bur. Fish., Wash. D. C. p. 3-24.

Murawski, S. A. 1993. Climate change and fish distributions: forecasting from historical analogy. Trans. Am. Fish. Soc. 122:647-658. (doi: https://doi.org/10.1577/ 1548-8659(1993)122<0647: CCAMFD >2.3. $\mathrm{CO} ; 2)$.

Myers, R. A. 1998. When do environmentrecruitment correlations work? Rev. Fish Biol. Fish. 8:285-305. (doi: https://doi.org/ 10.1023/A: 1008828730759 ).

Nels, G., S. Diederich, D. W.Thieltges, and M. Strasser. 2006. Wadden Sea mussel beds invaded by oysters and slipper limpets: competition or climate control? Helgol. Mar. Res. 60(2):135-143. (doi: https://doi.org/10.1007/ s10152-006-0032-9)

Newell, R. I. E., G. S. Alspach, Jr., V. S. Kennedy, and D. Jacobs. 2000. Mortality of newly metamorphosed eastern oysters (Crassostrea Virginica) in mesohaline Chesapeake Bay. Mar. Biol. 136:665-676. (doi: https://doi. org/10.1007/s002270050726).

S. T. Tettelbach, C. J. Gobler, and D. G. Kimmel. 2009. Relationships between reproduction in suspension-feeding hard clams Mercenaria mercenaria and phytoplankton community structure. Mar. Ecol. Prog. Ser. 387:179-196. (doi: https://doi.org/ 10.3354/meps08083).

Niven, D. K., G. S. Butcher, and G. T. Bancroft. 2013. Christmas bird counts and climate change: northward shifts in early winter abundance. American Birds. The $109^{\text {th }}$ Christmas Bird Count. p. 10-15.

Nixon, S. W. 1995. Coastal marine eutrophication: a definition, social causes, and future concerns. Ophelia 41:199-219. (doi: https:// doi.org/10.1080/00785236.1995.10422044).

NRC. 2000. Clean coastal waters: understanding and reducing the effects of nutrient pollution. Natl. Res. Counc., Natl. Acad. Press. Wash. D.C., 405 p.

Nuzzi, R., and R. M. Waters. 1989. The spatial and temporal distribution of "brown tide" in eastern Long Island. In E. M. Cosper, V. M. Bricelj, and E. J. Carpenter (Editors), p. 119158. Springer-Verl., N.Y.

Officer, C. B., R. B. Biggs, J. L. Taft, L. E. Cronin, M. A. Tyler, and W. R. Boynton. 1984. Chesapeake Bay anoxia: origin, development, and significance. Science 223:22-27. (doi: https://doi.org/10.1126/science.223.4631.22).

Orth, R. J., and K. A. Moore. 1983. Chesapeake Bay: An unprecedented decline in submerged aquatic vegetation. Science 222:51-53. (doi: https://doi.org/10.1126/science.222.4619.51). K. L. Heck, Jr., and J. van Montfrans. 1984. Faunal communities in seagrass beds: A review of the influence of plant structure and prey characteristics on predator-prey relationships. Estuaries 7(4A):339-350. (doi: https://doi.org/10.2307/1351618)

Ottersen, G., B. Planque, A. Belgrano, E. Post, P. C. Reid, and N. C. Stenseth. 2001. Ecological effects of the North Atlantic Oscillation. Oecologia. 128:1-14. (doi: https://doi. org/10.1007/s004420100655).

Oviatt, C. A. 2004. The changing ecology of temperate coastal waters during a warming trend. Estuaries 27(6):895-904.

P. Lane, F. French, III, and P. Donagha. 1989. Phytoplankton species and abundance in response to eutrophication in coastal marine mesocosms. J. Plankton Res. 11(6):1223-1224. (doi: https://doi.org/10 1093/plankt/11.6.1223)

A. Keller, and L. Reed. 2002 Annual primary production in Narragansett Bay with no bay-wide winter-spring phytoplankton bloom. Estuar. Coast. Shelf Sci. 54:1013-1026. (doi: https://doi.org/10.1006/ ecss.2001.0872).

S. Olsen, M. Andrews, J. Collie, T. Lynch, and K. Reposa. 2003. A century of fishing and fish fluctuations in Narragansett Bay. Rev. Fish. Sci. 11(3): 221-242. (doi: https://doi.org/10.1080/ 106412603902 44413).

Paerl, H. W. 2006. Assessing and managing nutrient-enhanced eutrophication in estuarine and coastal waters: interactive effects of human and climatic perturbations. Ecol. Engin. 26:40-54. (doi: https://doi.org/10.1016/j. ecoleng.2005.09.006)

Parsons, L. S., and W. H. Lear. 2001. Climate variability and marine ecosystem impacts: a North Atlantic perspective. Prog. Oceanogr. 49:167-188. (doi: https://doi.org/10.1016/ S0079-6611(01)00021-0)

Pearce, J., and N. Balcom. 2005. The 1999 Long Island Sound mortality event: Findings of the Comprehensive Research Initiative. J. Natl. Shellfish Assoc. 24(3):691-697. (doi: https:// doi.org/10.2983/0730-8000(2005)24[691:TLI SLM]2.0.CO;2)

Philippart, S. J. M., H. M. van Aken, J. J. Beukema, O. G. Bos, G. C. Cadée, and R. Dekker. 2003. Climate-related changes in recruitment of the bivalve Macoma balthica. Limnol. Oceanogr. 48(6):2171-2185. (doi: https://doi. org/10.4319/1o.2003.48.6.2171).
Pihl, L. 1985. Food selection and composition of mobile epibenthic fauna in shallow marine areas. Mar. Ecol. Prog. Ser. 22:169-279. and R. Rosenberg. 1984. Food selection and consumption of the shrimp Crangon crangon in some shallow marine areas in western Sweden. Mar. Ecol. Prog. Ser 15:159-168.

Platt, T., C. Fuences-Yaco, and K. T. Frank. 2003. Marine ecology: spring algal bloom and larval fish survival. Nature 423:398-399. (doi: https://doi.org/10.1038/423398b).

Polyakov, G., J. N. Kraeuter, E. E. Hofmann, S. C. Buckner, V. M. Bricelj, E. N. Powell, and J. M. Klink. 2007. Benthic predators and northern quahogs (=hard clam) (Mercenaria mercenaria) Linnaeus, 1758) populations. J. Shellfish Res. 26:995-1010. (doi: https://doi. org/10.2983/0730-8000(2007)26[995:BPAN QH]2.0.CO;2).

Powell, E. N., J. N. Kraeuter, and K. A. AshtonAlcox. 2006. How long does oyster shell last on an oyster reef? Estuar. Coast Shelf Sci. 69(3-4):531-542. (doi: https://doi. org/10.1016/j.ecss.2006.05.014).

Preston, B. L. 2004. Observed winter warming of the Chesapeake Bay Estuary (1949-2002): implications for ecosystem management. Environ. Manag. 34(1):125-139. (doi: https:// doi.org/10.1007/s00267-004-0159-x)

Prytherch, H. F. 1928. Predicting the intensity of oyster setting in northern waters. Fish. Gaz., April:16-17.

Purcell, J. E., and M. B. Decker. 2005. Effects of climate on relative predation by scyphomedusae and ctenophores on copepods in Chesapeake Bay during 1987-2000. Limnol. Oceanogr. 50(1):376-387. (doi: https://doi org/10.4319/1o.2005.50.1.0376)

F. P. Cresswell, D. G. Cargo, and V. S. Kennedy. 1991. Differential ingestion and digestion of bivalve larvae by the scyphozoan Chrysaora quinquecirrha and the ctenophore Mnemiopsis leidyi. Biol. Bull. 180:103-111. (doi: https://doi.org/10.2307/1542433).

Rabalais, N. N. 2002. Nitrogen in aquatic ecosystems. Ambio 31(2):102-12. (doi: https:// doi.org/10.1579/0044-7447-31.2.102).

Raffaelli, D. 2000. Interactions between macroalgal mats and invertebrates in the Ythan estuary, Aberdeenshire, Scotland. Helgol. Mar. Res. 54:71-79. (doi: https://doi.org/10.1007/ s101520050004).

Reise, K. 1993. Die verschwommene Zukunft der Nordseewatten. In H. J. Schellnhuber, and H. Sterr (Editors), Klimaanderung und Kuste, p. 223-232. Springer-Verl. Berl

Robertson, H. R. 1923. The creation of oyster set in Connecticut. Fish. Gaz., Jan., p. 45-46.

Ruano, F. D. L. 1997. Fisheries and farming of important marine bivalves in Portugal. In C. L. MacKenzie, Jr., V. G. Burrell, Jr., A Rosenfield, and W. L. Hobart (Editors), The history, present condition, and future of the molluscan fisheries of North and Central America and Europe. Volume 33. Europe, p. 191-200. U.S. Dep. Commer., NOAA Tech. Rep. NMFS 129.

Rumrill, S. S. 1990. Natural mortality of marine invertebrate larvae. Ophelia 32(1-2):163198. (doi: https://doi.org/10.1080/00785236. 1990.10422030).

Sanchez-Rubio, G., H. M. Perry, P. M. Biesiot, D. R. Johnson, and R. Lipcius. 2011. Climate-related hydrological regimes and their effects on abundance of juvenile blue crabs 
(Callinectes sapidus) in the northcentral Gulf of Mexico. Fish. Bull. 109 (2):139-146.

Sanders, H. L. 1956. Oceanography of Long Island Sound, 1952-1954. X. The biology of marine bottom communities. Bull. Bingham Oceanogr. Collect. 15:345-414

Seaman, M. N. L., and M. Ruth. 1997. The molluscan fisheries of Germany. In C. L. MacKenzie, Jr., V. G. Burrell, Jr., A. Rosenfield, and W. L. Hobart (Editors), The history, present condition, and future of the molluscan fisheries of North and Central America and Europe. Vol. 3, Europe, p. 57-84. U. S. Dep. Commer. NOAA Tech. Rep. NMFS 129.

Smayda, T. J. 1973. The growth of Skeletonema costatum during a winter-spring bloom in Narragansett Bay, Rhode Island. Norw. J. Bot. 20:219-247.

1990. Novel and nuisance phytoplankton blooms in the sea: evidence for a global epidemic. In E. B. Graneli, L. Sunderstrom, L. Edler, and D. M. Anderson (Editors). Toxic marine phytoplankton, p. 29-40. Elsevier, N.Y.

D. G. Borkman, G. Beaugrand, and A. G. Belgrano. 2004. Ecological effects of climate variation in the North Atlantic: phytoplankton. In N. C. Stenseth, G. Ottersen, J. Hurrell, and A. Belgrano (Editors), Ecological effects of climate variations in the North Atlantic, p. 49-54. Oxford Univ. Press.

Snelgrove, P.V.R., J. P. Grassle, J. F. Grassle, R. F. Petrecca, and H. Ma. 1999. In situ habitat selection by settling larvae of marine soft-sediment invertebrates. Limnol. Oceanogr. 44(5):1341-1347. (doi: https://doi. org/10.4319/10.1999.44.5.1341).

Sogard, S. M., and K. W. Able. 1991. A comparison of eelgrass, sea lettuce macroalgae, and marsh creeks as habitats for epibenthic fishes and decapods. Estuar. Coast. Shelf Sci. 33:501-519. (doi: https:// doi.org/10.1016/0272-7714(91)90087-R).

Soniat, T. M., J. M. Klink, E. N. Powell, and E. E. Hofmann. 2009. Differential modulation of eastern oyster (Crassostrea virginica) disease parasites by the El-Niño-Southern Oscillation and the North Atlantic Oscillation. Int. J. Earth Sci. 98:99-114. (doi: https://doi. org/10.1007/s00531-008-0364-6).

J. M. Klink, E. N. Powell, and E. E. Hofmann. 2012a. Understanding the success of oyster populations: periodicities of Perkinsus marinus, and oyster recruitment, mortality, and size. J. Shellfish. Res. 31(3):635-646. (doi: https://doi.org/10.2983/035.031.0307).

J. M. Klinck, E. N. Powell, N. Cooper, M. Abdelguerfi, E. Hoffman, J. Dahal, S. Tu, J. Finigan, B. S. Eberline, J. F. LaPeyre, M. K. LaPeyre, and F. Qaddoura, 2012b. A shell-neutral approach yields sustainable oyster harvest estimates: a retrospective analysis of the Louisiana state primary seed grounds. J. Shellfish. Res. 31(4):1103-1112. (doi: https://doi.org/10.2983/035.031.0421).

Steinberg, P. D., and V. S. Kennedy. 1979. Predation upon Crassostrea virgnica (Gmelin) larvae by two invertebrate species common to Chesapeake Bay oyster bars. Veliger 22:78-84.

Stenseth, N. C., A. Mysterud, G. Ottersen, J. W. Hurrell, K. Chan, and M. Lima. 2002. Ecological effects of climate fluctuations. Science 297:1292-1296. (doi: https://doi.org/10.1126/ science.1071281)
Straile, D., and N. C. Stenseth. 2007. The North Atlantic Oscillation and ecology: links between historical time-series, and lessons regarding future climate warming. Clim. Res. 34:259-262. (doi: https://doi.org/10.3354/ cr00702).

Strasser, M. 2002. Reduced epibenthic predation on intertidal bivalves after a severe winter in the European Wadden Sea. Mar. Ecol. Prog. Ser. 241:113-123. (doi: https://doi. org/10.3354/meps241113).

and C.-P Günther. 2001. Larval supply of predator and prey: temporal mismatch of crabs and bivalves after a severe winter in the Wadden Sea. J. Sea Res. 46(1):57-67. (doi: https://doi.org/10.1016/ S1385-1101(01)00063-6)

A. Hertlein, and K. Reise 2001 Differential recruitment of bivalve species in northern Wadden Sea after the severe winter of 1995/96 and of subsequent milder winters. Helgol. Mar. Res. 55(3):182-189. (doi: https://doi.org/10.1007/s101520100080)

Sullivan, B. K., D. Van Keuren, and M. Clancy. 2001. Timing and use of blooms of the ctenophore Mnemiopsis leidyi in relation to temperature in Narragansett Bay, Rhode Island. Hydrobiologia 451:113-120. (doi: https://doi. org/10.1023/A:1011848327684).

Sunila, I., J. Karolus, and J. Volk. 1999. A new epizootic of Haplosporidium nelsoni (MSX), a haplosporidian oyster parasite in Long Island Sound, Connecticut. J. Shellfish. Res. 18:169-174. (doi: https://doi. org/10.2983/035.034.0211)

Sutherland, D. L., and S. J. Koplin. 1997. Mollusk statistical data collection in the United States. In C. L. MacKenzie, Jr., V. G. Burrell, Jr., A. Rosenfield, and W. L. Hobart (Editors) The history, present condition, and future of the molluscan fisheries of North and Central America and Europe, p. 189-197. Vol. 2, Pacific Coast and supplemental topics. U.S. Dep. Commer., NOAA Tech. Rep. NMFS 128

Tang, Y. Z., and C. J. Gobler. 2009. Cochlodinium polykrikoides blooms and clonal isolates from the northwest Atlantic coast cause rapid mortality in larvae of multiple bivalve species. Mar. Biol. 156:2601-2611. (doi: https:// doi.org/10.1007/s00227-009-1285-z)

Taylor, D. L., S. W. Nixon, S. L. Granger, B. A. Buckley, J. P. McMahon, and H. J. Lin. 1995. Responses of coastal lagoon plant communities to different forms of nutrient enrichment-a mesocosm experiment. Aquat. Botany 52:19-34. (doi: https://doi. org/10.1016/0304-3770(95)00485-I)

Trice, T. M., P. M. Glibert, and L. Van Heukelem. 2004. HPLC pigment ratios provide evidence of past blooms of Aureococcus anophagefferens in the coastal bays of Maryland and Virginia, USA. Harmful Algae 3:295-304. (doi: https://doi.org/10.1016/j. hal.2004.06.010).

Tulp, I., L. J. Bolloe, E. Meesters, and P. de Vries. 2012. Brown shrimp abundance in northwest European coastal waters from 1970 to 2010 and potential causes for contrasting trends. Mar. Ecol. Prog. Ser. 458:141-154. (doi: https://doi.org/10.3354/meps09743).

Tunberg, B. G., and W. G. Nelson. 1998. Do climatic oscillations influence cyclical patterns of soft bottom macrobenthic communities on the Swedish west coast. Mar. Ecol. Prog.
Ser. 170:85-94. (doi: https://doi.org/10.3354/ meps170085).

Turner, A. 1910. Oysters as food. Health Culture 14:486-490

Turner, J. T., D. G. Borkman, and C. D. Hunt. 2006. Zooplankton of Massachusetts Bay, USA, 1992-2003: relationships between the copepod Calanus finmarchicus and the North Atlantic Oscillation. Mar. Ecol. Prog. Ser 311:115-124. (doi: https://doi.org/10.3354/ meps311115)

Tyler, R. M. 2007. Effects of coverage by benthic seaweed mats on (northern quahog=hard clam) Mercenaria mercenaria in a eutrophic estuary. J. Shellfish Res. 26:1021-1028. (doi: https:// doi.org/10.2983/0730-8000(2007)26[1021:EOCBBS]2.0.CO;2).

Van Beusekom, J. E. E., M. Loebl, and P. Martens. 2009. Distant riverine nutrient supply and local temperature drive the long-term phytoplankton development in a temperate coastal basin. J. Sea Res. 61:26-33. (doi: https://doi.org/10.1016/j.seares.2008.06.005).

van der Veer. H. W., and M. J. N. Bergman 1987. Predation by crustaceans on a newly settled 0-group plaice Pleuronectes platessa population in the western Wadden Sea. Mar Ecol. Prog. Ser. 35:203-215.

R. J. Fellerb, A. Webera, and J.

IJ. Wittea. 1998. Importance of predation by crustaceans upon bivalve spat in the intertidal zone of the Dutch Wadden Sea as revealed by immunological assays of gut contents. J. Exp. Mar. Biol. Ecol. 231(1):139-157. (https://doi org/10.1016/S0022-0981(98)00090-2).

Von Drehle, D. 2013. Cull of the Wild. Time Magazine 182(24):36-42

Vaz-Pinto, F., C. Olabarria, I. Gestoso, E. Cacabelos, M. Incera, and F. Arenas. 2013. Functional diversity and climate change: effects on the invasibility of macroalgal assemblages. Biol. Invasions 15(8):1,833-1,846. (doi: https://doi.org/10.1007/s10530-013-0412-4).

Wall, C. C., B. J. Peterson, and C. J. Gobler 2011. The growth of estuarine resources (Zostera marina, Mercenaria mercenaria, Crassostrea virginica, Cyprinodon variegatus) in response to nutrient loading and enhanced suspension feeding by adult shellfish. Estuar. Coasts. 34(6):1261-1277. (doi: https://doi.org/10.1007/s12237-011-9377-7). C. P. Gohler, B. J. Peterson, and J. E. Ward 2013. Contrasting growth patterns of suspension-feeding molluscs (Mercenaria mercenaria, Crassostrea virginica Argopecten irradians, and Crepidula fornicata) across a eutrophication gradient in the Peconic Estuary, NY, USA. Estuar. Coasts 36:1274-1296. (doi: https://doi.org/10.1007/ s12237-013-9632-1)

Wasniak, C. E., and P. M. Glibert. 2004. Potential impacts of brown tide, Aureococcus anophagefferens, on juvenile hard clams, Mercenaria mercenaria, in the coastal bays of Maryland, USA. Harmful Algae 3:321-329. (doi: https://doi.org/10.1016/j. hal.2004.06.004)

Webster, J. R., and R. Z. Medford. 1961. Flatworm distribution and associated oyster mortality in Chesapeake Bay. Proc. Natl. Shellfish. Assoc. 50:89-95.

Weinberg, J. R. 2005. Bathymetric shift in the distribution of Atlantic surfclams: response to warmer ocean temperatures. ICES J. Mar. Sci. 62:1444-1456. (doi: https://doi.org/10.1016/j. icesjms.2005.04.020). 
Wells, H. W. 1957. Abundance of the hard clam Mercenaria mercenaria in relation to environmental factors. Ecology 38:123-128. (doi: https://doi.org/10.2307/1932134).

White, M. E., and E. A. Wilson. 1996. Predators, pests and competitors. In V. S. Kennedy, R. I. E. Newell, and A. E. Eble (Editors), The eastern oyster Crassostrea virginica, p. 559579. Md. Sea Grant Coll., Coll. Park, Md.
Whitney, G. G. 1994. From coastal wilderness to fruited plain. A history of environmental change in temperate North America from 1500 to the present. Camb. Univ. Press, N.Y., $488 \mathrm{p}$.

Woods, H., W. J. Hargis, Jr., C. H. Hershner, and P. Mason. 2005. Disappearance of the natural emergent 3-dimensional oyster reef system of the James River, Virginia, 1871-1948. J.
Shellfish Res. 24(1):139-142. (doi: https:// doi.org/10.2983/0730-8000(2005)24[139:DO TNED]2.0.CO;2).

Zimmerman, R. C., R. D. Smith, and R. A Alberte. 1989. Thermal acclimation and whole-plant carbon balance in Zostera marina (eelgrass). J. Exp. Mar. Biol. Ecol. 130(2):93-109. (doi: https://doi.org/10.1016/ 0022-0981(89)90197-4). 


\section{Appendix}

We believe the increases in landings of lobsters in Maine and the Canadian Maritimes occurred because predation by the cod, Gadus morhua, and perhaps spiny dogfish, Squalus acanthias, on young lobsters fell sharply. Since 1994, the cod landings have fallen sharply while the lobster landings have increased sharply there (NOAA Landings Statistics). Any changes in the abundance of the spiny dogfish cannot be estimated reliably using landings data.

Maine lobster landings have increased 5.5-times in magnitude from the early 1980's to 2011 (Fig. A1). From the early 1950's and into the 1980's, the annual landings had remained nearly steady at 18-20 million $\mathrm{lb}(\mathrm{mlb})$ (8.2-9 million $\mathrm{kg}(\mathrm{mkg})$ ). They then began to rise: in 1990, the landings were $28 \mathrm{mlb}(12.7 \mathrm{mkg})$; in 2000, $57 \mathrm{mlb}$ (26 mkg); in 2005, 69 $\mathrm{mlb}(31 \mathrm{mkg})$; in 2010, $96 \mathrm{mlb}$ (43.6 $\mathrm{mkg}$ ); and in 2011, $105 \mathrm{mlb}$ (47.7 $\mathrm{mkg}$ ). The rises were due to increases in both lobster abundance and fishing effort. The numbers of fishermen are limited but the numbers of fishing licenses still increased from 5,152 in 1950 to 5,963 in 2013, while the numbers of traps increased from 430,000 in 1950 to $2,976,000$ in 2013. As far as is known, the increase in landings resulted mostly from the increase in lobster abundances (authors' observ.).

Records of lobster landings from the inshore regions, from Massachusetts to Virginia, are unavailable because a substantial portion of landed lobsters are potted in deep ocean waters outside the coastal zones; the official government landings data from inshore and offshore locations are lumped together. A record of lobster landings in Long Island Sound is from only Connecticut, whose waters extend half way across the sound to meet New York waters, and from the New York-Connecticut border just east of New York City to Saybrook, Conn., an east-west distance of about $110 \mathrm{~km}$. This encompasses about $70 \%$ of the distance across the Connecticut coast.

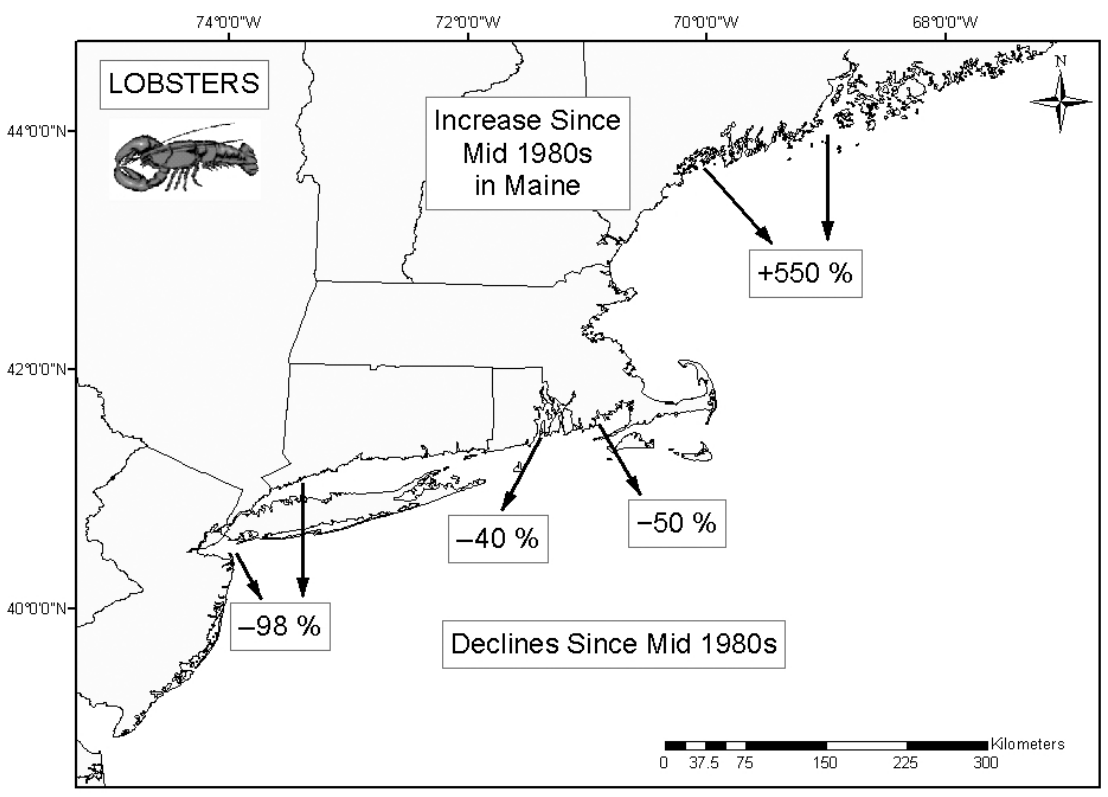

Figure A1.--Increase in lobster landings in Maine and decreases in their landings between Buzzards Bay, Mass., and New Jersey.

The Connecticut lobster landings were increasing steadily from $1,060,000 \mathrm{lb}(482,000 \mathrm{~kg})$ in 1984 to $2,584,000 \mathrm{lb}(1,174,545 \mathrm{~kg})$ in 1998 . They then declined sharply because a large lobster die-off occurred in the sound in 1999. The landings totaled just $154,000 \mathrm{lb}(70,000 \mathrm{~kg})$ in 2007 , down by $94 \%$. According to Pearce and Balcom (2005), the principle reason for the lobster die-off was water temperatures rising too high in 1999: temperatures increased from an $18^{\circ}-$ $19^{\circ} \mathrm{C}$ range to a range of $20^{\circ}-22^{\circ} \mathrm{C}$. They said that the warmer waters may have accelerated an increase in abundance of the amoeba, Neoparamoeba pemaquidensis, that parasitizes and likely weakens lobsters, and besides low dissolved oxygen at the water-sediment interface, coupled with the release of sulfides and ammonium rising from the sediments, killed nearly all the lobsters and with them likely the rock crabs, $C$. irroratus.

Data on landings of lobsters in Raritan Bay, N.J., and upper New York Bight have never been recorded, but a decline in their abundances and landings can be estimated by examining fishing effort. This fishery began in the 1700 's, and then may have continued onward. During the 1950's to early 1990 's, about 28 boats with crews of 2 men each trapped lobsters daily from June to October every year. The boats each lifted about 300 pots/day (MacKenzie, 1990, 1992). During the 1990's, the fishermen found few lobsters and eventually almost none in their pots, and by the early 2000's, this fishery had ended. ${ }^{1}$

An epizootic lobster shell disease appeared in the inshore waters of Rhode Island and Connecticut during the late 1990's (Castro and Angell, 2000). The prevalence rates of this disease have been $10 \%-40 \%$ in Rhode Island waters, but there is no evidence that lobster abundance had declined due to shell disease. By 1997, though, a sharp decline in landings and population indices was recorded and it continued thereafter. No one precisely knows what factor was responsible for the lobster declines, but it is suggested that water temperature became too high (Gomez-Chiarri and Cobb, 2012).

${ }^{1}$ Fishermen interviews and personal observations. 


\section{Literature Cited}

Castro, K. M., and T. E. Angell. 2000. Prevalence and progression of shell disease in American lobster, Homarus americanus, from Rhode Island waters and offshore canyons. J. Shellfish Res. 19:691-700.

Gomez-Chiarri, M., and J. S. Cobb. 2012. Shell disease in the American lobster, Homarus americanus: a synthesis of research from the New England lobster research initiative: lobster shell disease. J. Shellfish Res. 31(2):583-590. (doi: https://doi. org/10.2983/035.031.0219)

MacKenzie, C. L., Jr. 1990. History of the fisheries of Raritan Bay, New York and New Jersey. Mar. Fish. Rev. 52(4):1-45.
1992. The fisheries of Raritan Bay. Rutgers Univ Press, New Brunswick, N.J., $304 \mathrm{p}$.

Pearce, J., and N. Balcom. 2005. The 1999 Long Island Sound mortality event: Findings of the Comprehensive Research Initiative. J. Natl Shellfish Assoc. 24(3):691-697. (doi: https:// doi.org/10.2983/0730-8000(2005)24[691:TLI SLM]2.0.CO;2) 